\begin{tabular}{|c|c|c|}
\hline & $\begin{array}{l}\text { BŞEÜ Sosyal Bilimler Dergisi } \\
6(2), 484-503,2021\end{array}$ & $\begin{array}{r}\text { BSEU Journal of Social Sciences } \\
\text { https://doi.org/10.33905/bseusbed.1027257 }\end{array}$ \\
\hline $\begin{array}{l}\text { BILECIKSEYYHEDEB ER } \\
\text { ONIVERSITE }\end{array}$ & $e-I S S \Lambda$ & 2548-088X (https://dergipark.org.tr/tr/pub/bseusbed) \\
\hline
\end{tabular}

Araştırma Makalesi- Research Article

\title{
İngiltere'nin Avrupa Birliğinden Ayrılış Sürecinde Göç Faktörünün Etkisi
}

\section{The Effect of Migration in the Britain's European Union Exit Process}

\author{
İsmail Hakkı İ̧CAN ${ }^{1 *}$
}

Geliş / Received: 22/11/2021

Revize / Revised: 16/12/2021

Kabul / Accepted: 16/12/2021

\begin{abstract}
öZ
Sancılı bir başvuru sürecinden sonra 1973 yılında İrlanda ve Danimarka ile birlikte Avrupa Birliği (AB) üyeliğine kabul edilen İngiltere AB için, iç politika bağımsızlığı ve bazı egemenlik haklarının devri konularında her zaman sorun oluşturmuştur. İngiltere, AB'nin yürürlüğe koyduğu birçok ulus üstü ve hükûmetler arası anlaşmalardan kendini ayrıştırmayı başarmıştır. Brexit, bu ayrışmanın en kalıcısıdır. Brexit sürecinde göç konusunun yoğun bir şekilde propaganda aracı olarak kullanıldığı görülmektedir. İstatistiklere bakıldığında İngiltere için göç konusundaki sorunun bölge dışı olmaktan ziyade Birlik üyesi diğer ülkelerle olan göçmen hareketliliğinden kaynaklı olduğu anlaşılmaktadır. Bu çalışma göçün $\mathrm{AB}$ içerisinde ve İngiltere özelinde yarattığı ekonomik ve güvenlik kaynaklı etkilerini araştırırken, Brexit sürecinin göç konusu ile ilişkisini tartışmaktadır. Anlaşıldığı kadarıyla gerek AB ülkeleri ve gerekse İngiltere, göçle birlikte oluşan sosyal değişimi bir güvenlik tehdidi olarak ele almaktadırlar. Gelişmiş ve hedef ülkeler kendilerini bu tehdide karşı korumak ve göçü bir şekilde engellemek için her türlü politik tedbiri almak durumunda ve dahası bu hakka sahip hissetmektedirler.
\end{abstract}

Anahtar Kelimeler- Brexit, Göç, Avrupa Birliği, Suriyeli Mülteciler.

\begin{abstract}
After a painful application process, Britain, was admitted to the European Union (EU) together with Ireland and Denmark in 1973. It has always been a problem in terms of internal policy independence and transfer of some sovereign rights for the EU. Britain has succeeded in decoupling from many supranational and intergovernmental agreements put into effect by the EU. Brexit is the most permanent of this divergence. In the Brexit process, it is seen that immigration is used as a propaganda tool. Considering the statistics, it is understood that the problem regarding immigration for the Britain is due to immigrant mobility with other member countries of the Union rather than being outside the region. This study investigates the economic and security-based effects of migration in the EU and in the Britain, while also discussing the relationship between the Brexit process and the issue of migration. It is understood that both the EU countries and the Britain consider the social change that occurs with immigration as a security threat. Developed and target countries have to take all kinds of political measures to protect themselves against this threat and prevent migration, and moreover, they feel they have this right.
\end{abstract}

Keywords- Brexit, Migration, European Union, Syrian refugees.

\footnotetext{
1* Sorumlu Yazar, Prof. Dr., Bilecik Şeyh Edebali Üniversitesi, İktisadi ve İdari Bilimler Fakültesi, İktisat Bölümü, ismailhakki.iscan@bilecik.edu.tr, (https://orcid.org/0000-0003-2786-4928)
} 


\section{GİRIŞ}

Genel sözlüklerde yapılan tanımlamalar dışında göç (migration) ve göçmen (migrant) kavramları, yasal, idari, bilimsel ve istatistiksel alanlar da dâhil olmak üzere farklı ve özel tanımlamalara sahiptir. Göç ve göçmen kavramlarının tanımlamaları, ilişkili kavramları ve kategorileri, coğrafi, yasal, politik, metodolojik ve benzeri faktörlerle yakından ilgilidir. Göç olaylarının tanımlamasında örneğin, doğum yeri, vatandaşlık, ikamet yeri ve kalış süresi gibi faktörlerce belirlenen sayısız yol vardır. Göç ve göçmenlerin etkilerini ölçmek ve analiz etmek söz konusu olduğunda tanımlama önem arz etmektedir. Buna göre Birleşmiş Milletler (BM) göçmen kavramını, "her zamanki ikamet ettiği ülkesini değiştiren herhangi bir kişi”" olarak tanımlar (UNDESA, 1998: 9).

Bu tanımlamaya göre uluslararası göçmen, ayrıldığı ülkede normal bir ikamet sahibi olan, girdiği ülkede normal bir ikamet sahibi olmamakla birlikte bir ikamet kuracak olan kişidir. Bu tanımın kullanılması, göçle ilgili uluslararası düzeyde karşılaştırılabilir verilerin toplanmasına imkân sağlamaktadır. BM, böyle bir tanımlamanın ulusal veri sistemleri tarafından benimsenmesini tavsiye etmesine rağmen, uluslararası göçmenin her ülkede kullanılan idari ve yasal tanımlamalarıyla karıştırılmamalıdır. Yani uluslararası göçmenle ilgili ulusal uygulamalarda yer alan temel kavramların ve tanımlamaların çoğu zaman BM tarafından önerilen kavram ve tanımlamalardan farklı olabileceği unutulmamalıdır. BM'nin çeşitli raporlarda ülkeler bazında sunduğu uluslararası göçmen sayılarına ilişkin istatistikler, BM tarafından önerilenleri değil, ulusal tanımlamaları yansitmaktadır (IOM, 2017: 299-300). Ülkeler arasında kavram ve tanımlamalardaki farklılıklarla veri toplama metodolojilerindeki uyumsuzluklar, uluslararası göçmenlerle ilgili ulusal bazdaki istatistiklerin karşılaştırılabilirliğini önemli ölçüde engellemektedir.

Göç konusunda uluslararası düzeyde yaşanan kavramsal kargaşaya önem atfetmemizin nedeni, Birlik genelinde şu ana kadar tutarlı bir göç politikası geliştiremeyen Avrupa Birliği (AB) için göç olgusunun, geçmişte ve şu anda ifade ettiği anlam ve algı farklılığıdır. Zira AB bir zamanlar göçü siyasi bütünleşmesinin tamamlayıcı bir unsuru olarak değerlendirirken, göçün ekonomik etkileri üzerinde yoğunlaşmıştır. Özellikle AB'nin genişleme dönemlerinde yürütülen kontrollü göç hareketliliğinin AB'nin kurumlarınca Birliğin ekonomik büyümesine katk1 sağlayacağı düşünülmüştür. Nitekim Avrupa Komisyonu ve OECD tarafindan ortaklaşa oluşturulan ve 2014 yılında yayımlanan raporda Avrupa'nın ihtiyaç duyduğu niteliklere sahip iş gücünü çekebilmek için diğer ekonomilerle rekabet ettiği, 2012 ile 2025 yılları arasında AB'nin gerektirdiği iş gücü niteliğinde, yüksek eğitimli iş gücü istihdamının keskin bir artış göstereceğinin beklendiği (\%23 oranında) ifade edilmektedir (Descy, 2014) AB'nin göçe yönelik ilk eylem planı olan ve Avrupa Komisyonunun Mayıs-2015'de yayınlanan “Avrupa Göç Gündemi” başlıklı raporunda ise AB için yasal göçün hem kaynak ve hem de hedef ülkeler için olumlu ekonomik sonuçları üzerinde tespitler yapmaktadır. Aynı raporda üye ülkelerin konu hakkında acil eylem planları oluşturulması gerekliliği vurgulanırken kararlı bir çabayla bile orta ve uzun vadede AB iş gücü piyasasındaki ihtiyaçların tam olarak karşılanamayacağı belirtilmektedir. Raporda düzensiz göçün $\mathrm{AB}$ açısından göçü bir sorun haline getireceği ve AB Delegasyonlarının göçü temel bir sorun olarak ele almaları gerektiği de ayrıca vurgulanmaktadır (EC, 2015).

AB’nin kurucu anlaşmaları olan 1951 Paris ve 1957 Roma Anlaşmalarında, üye ülke vatandaşlarına Birlik içerisinde bulunan ülkelerde çalışma imkânı ve üye ülke işçilerine bir diğer üye ülkede serbest dolaşım hakkı sağlanmıştır. Bu özgürlük zamanla daha da genişletilerek 1993 Maastricht Anlaşması ile bir vatandaşlık hakkı haline getirilmiştir. Bununla birlikte serbest dolaşım hakkı giderek Birlik için bir güvenlik sorunu haline gelmeye başlamış özellikle düzensiz göçle mücadelede geliştirilen politika ve önlemlerin bu hakla birlikte yürütülmesi sağlanmaya çalışılmıştır.

Soğuk Savaş sonrası Doğu ve Batı Almanya’nın birleşmesi, küreselleşmede yaşanan gelişmeler ve Doğu Avrupa ülkelerinde liberal ekonomi politikalarına geçiş süreci, Avrupa'da doğudan batıya doğru göç hareketlerini tetiklemiş, bu durum ev sahibi ülkelerde toplumsal önyargıların oluşmasına, ekonomi ve siyasette göç karşıtlığını gündeme taşıyarak Avrupa'da göç ve güvenlik sorunlarının birbirleri ile ilişkilendirildiği bir ortam meydana getirmiştir (Maas, 2008: 16-17).

1990’lı yıllarla birlikte yaşanan bu durum Avrupa'da göçün, istihdam üzerinde oluşturduğu etkilerle birlikte toplumsal önyargı ve yabancı karşıtlığı ile siyasallaşması sonuçlarını da doğurmuştur. Günümüz şartlarında hem AB kurumları hem de Birlik üyesi ülkeler için göç, ekonomik olmaktan ziyade siyasi ve hatta güvenlik endişeleri ile bezenmiş bir sorun haline gelmiştir. AB Konseyi Genel Sekreterliği tarafından 2003 yılında hazırlanan AB Güvenlik Stratejisi belgesinde terörizm ve organize suçlarla birlikte düzensiz göç de güvenlik tehdidi olarak görülmüş ve terörle bağlantılı konularla birlikte AB politika metinlerine girmiştir (CEU, 2009: 7). 
Ayrıca Avrupa toplumlarının göçü sosyoekonomik birçok sorunla eşleştirmesi ve artan bir tehdit ve güvensizlik unsuru olarak görmesi, Avrupa devletlerine normalde meşru sayılamayacak çeşitli kontrollerin göçe karşı uygulanmasını haklı gösterecek bir siyasi ortam da sağlamıştır (Boswell, 2007: 590).

Bu çalışmada Avrupa'da önemli bir endişe kaynağı haline gelen göçün ekonomik yönden bir endişe mi yoksa çeşitli argümanlarla ortaya konabilecek farklı bir sorun mu olduğu araştırılacaktır. Bu kapsamda çalışmanın iki amacından biri Brexit sürecinin bölge içi ve bölge dışı kaynaklı göç sorunu ile ilgili olup olmadığını ortaya koymaktır. Çalışmanın diğer amacı ise Suriye'de baş gösteren iç karışıklıklar dolayısıyla göçe maruz kalan mültecilerin $\mathrm{AB}$ içerisinde ve Birleşik Krallık ${ }^{2}$ özelinde yarattığ 1 etkiyi ortaya koyarak Brexit süreci ile ilgisinin gerçekçiliğini tartışmaktır. Çalışmanın izleyen bölümünde $A B$ göç politikaları ve göç yönetimi üzerinde açıklamalar getirilecek ve sonrasında İngiltere'nin AB'den ayrılış süreci ve bu süreçte göçün etkisi araştırılacaktır. Sonuç bölümü öncesinde İngiltere özelinde göçün durumu ele alınarak göç kaynaklı endişenin emek piyasası temelli ekonomik bir sorun mu yoksa toplumsal endişelerle bezenmiş bir güvenlik sorunu mu olduğu tartışlacaktır. Çalışmada göçe dair istatistikler için, bazı düşünce kuruluşlarının göçe dair hazırladığı raporlar yanında BM ve BM'ye bağlı Mülteciler Yüksek Komiserliği (UNHCR)'nin verileri kullanılmış, aynı zamanda İngiltere Ulusal İstatistik Ofisinin (Office for National Statistics-ONS) de çeşitli rapor ve istatistikleri çalışma boyunca değerlendirilmiştir.

\section{AB POLITIKKALARINDA GÖÇ VE YÖNETIMI}

Avrupa için uluslararası göç konusu, İkinci Dünya Savaşı sonrası dönemde yoğunluk kazanmaya başlamış, bu durum bir taraftan Avrupa ülkeleri arasında siyasi bütünleşme sürecinin bir tehdidi olarak görülürken aynı zamanda ekonomik bütünleşme sürecinin de tamamlayıcı bir unsuru olarak değerlendirilmiştir. Avrupa'daki bütünleşmenin genişleme dönemlerinde Avrupa kamuoyu, genişleyen coğrafyalardan gelecek göç hareketliliğine karşı rahatsızlığını bir şekilde dillendirirken, Birliği oluşturan kurumlar da, kontrollü göç hareketliliğinin Birliğin ekonomik büyümesine katkı sağlayabileceği ihtimali üzerinde yoğunlaşmıştır.

Dünya üzerinde istikrarsızlaşan alanlardan daha istikrarlı bölgelere doğru bir göç başladığında Avrupa coğrafyası daima temel yönelimlerden biri olmuştur. Ancak buna rağmen $\mathrm{AB}$, günümüze kadar gelen süreç içerisinde tam bir göç ve sığınma politikası geliştirememiştir. AB'nin göç yönetiminde her üye devlet kendi çıkarlarını gözetirken her ülkenin de kendine özgü özellikleri ve politikaları bulunmakta ve bir diğerine benzememektedir. Bu durum ise göç ile ilgili her üye devletin kendine özgü hukuksal düzenlemelerinin ortaya çıkmasına neden olmakta ve konu ile ilgili $\mathrm{AB}$ düzeyinde ortak bir politikanın üretilmesini ve/veya uygulanmasını zorlaştırmaktadır.

Tarihsel olarak bakıldığında $\mathrm{AB}$ 'deki nüfus artışı büyük ölçüde doğal nüfus değişiminden (toplam doğum sayısı-toplam ölüm sayısı) kaynaklanmaktadır. Ancak İkinci Dünya Savaşı'ndan sonra doğum oranlarındaki azalma dolayısıyla 1970'lerden itibaren doğal nüfus artış hızı yavaşlamaya başlamıştır. 1990'lı yıllarda AB'deki genişleme dalgaları ve Avrupa tek pazarının gelişmesiyle birlikte ekonomik birliğe doğru hızlı yöneliş, nüfus sayısındaki genel değişiklikleri açıklamak için net göçün (gelen ve giden göç arasındaki fark) kullanılmasını gerekli kılmıştır (EU, 2018: 38). Yani 1990'lı yıllardan sonra AB'nin demografik genişlemesindeki esas unsur göçtür.

$\mathrm{AB}$ ülkelerini göç ve göçmenler için cazip kılan en önemli hususlardan biri şüphesiz ekonomik unsurdur. Birlik üyesi ülkelerin ekonomik olarak zengin olması, özellikle Avrupa dışı göçmenler için bu coğrafyayı cazip kılmaktadır. Coğrafi olarak büyük sayılamayacak bir bölgede demografik değişimin ve hareketliliğinin getirdiği nüfus yoğunluğundaki artış $\mathrm{AB}$ 'yi etkin ve tutarlı bir göç politikası oluşturma gerekliliğine itmiş̧tir. Bu doğrultuda ekonomik ve siyasi bütünleşme süreci içerisinde özgür, güvenlikli ve adalet ilkesi ile bütünleşik bir alan meydana getirmeye çalışırken aynı zamanda $\mathrm{AB}$ için uluslararası göç konusu, muhtemel bir güvenlik konusu haline geleceği endişesi ile 1999 Amsterdam Anlaşması'ndan itibaren AB gündeminin üst sıralarında yer almaya başlamıştır.

\footnotetext{
${ }^{2}$ Büyük Britanya (Great Britain), İngiltere, İskoçya ve Galler'i içine alan oluşumu ifade eden coğrafi bir terimdir. Birleşik Krallık (United Kingdom) ise İngiltere, Galler, İskoçya ve Kuzey İrlanda olmak üzere dört ana ülkeden oluşur. Birleşik Krallık için, Büyük Britanya ve Kuzey İrlanda Birleşik Krallığı (United Kingdom of Great Britain and Northern Ireland) da denebilmektedir. Bu devletler, İrlanda Adası'ndaki Kuzey İrlanda hariç hepsi Büyük Britanya adasındadır. Uluslararası camiada her iki terim de birbiri yerine kullanılabilirken, İngiltere ismi de zaman zaman resmi kanallarda Birleşik Krallık yerine kullanılmaktadır (T.C. Dışişleri Bakanlığı, 2019). İngiltere Birleşik Krallığı oluşturan bu dört ülkeden birisi ancak Egemen ülke konumundadır. Bu ayırımın önemi, Brexit oylamasında bu dört ülkenin de Brexit'e farklı tepkiler vermesiyle ilgilidir. Zira 23 Haziran 2016 tarihinde yapılan halk oylamasında AB'den ayrılmaya İngiltere \%53,4, Galler \%52,5 "Evet" derken, İskoçya \%62 ve Kuzey İrlanda \%55,8 oranı ile "Hayır” demiş, sonuçta \%52 ile AB'den ayrılma kararı çıkmıştır. Bu çalışmada bölgeyi temsil eden coğrafi kavram olarak "İngiltere” kullanılacaktır.
} 
Dolayısıyla $\mathrm{AB}$, üye ülkeler arasında başarabildiği ölçüde düzensiz göçle mücadele ve sınır kontrollerinin yaygınlaştırılması politikalarını etkinleştirmeye çalışmıştır.

Bunu gerçekleştirirken AB’nin göç yönetimi ve politikalarında genel olarak üç evreden bahsetmek mümkündür. Avrupaya gelen göçün ilk evresi, II. Dünya Savaşından sonra gelişmekte olan ülkelerden gelişmiş ülkelere doğru savaşın getirdiği yıkımı onarmak ve normale dönme çabası içerisinde geçici misafir işçilerin davet edilmesi politikasıdır. Bu dönemde Batı Avrupa'ya yaklaşık on milyon kişinin göç ettiği tahmin edilmektedir (Stalker, 2002: 152-153). Avrupa'da bu dönem göç alan ülkeler arasında başta Almanya olmak üzere İngiltere, Fransa ve Hollanda yer almaktadır (Zimmermann, 2005, s. 4). Bu dönem, göçmenlerin geldikleri ülke ekonomilerine önemli katkı sağladıkları, dolayısıyla uluslararası göçlerin kısıtlama getirmek bir yana teşvik ve kontrolünün sağlandığı bir dönemdir (Schmelz, 2008: 10).

Diğer taraftan aynı tarihlerde Avrupa ülkeleri arasındaki bütünleşme hareketleri de Avrupa'ya yönelik göç hareketlerini etkileyen bir başka unsurdur. Bu doğrultuda AB'nin gelişimi ile göç politikalarının gelişimini aynı doğrultudaki gelişmeler olarak değerlendirmek mümkündür. Bugünkü AB'nin 1951'den günümüze uzanan tarihinde ortaya çıkan ekonomik büyümesinin en önemli girdilerinden birisi, Avrupa'ya çevre ülkelerden gelen milyonlarca göçmen işçidir (Canpolat ve Arıner, 2012: 11).

AB’nin göç yönetimi ve politikalarında sonraki aşama, misafir olarak gelen ve davet edildiği ülkede yaşamlarını kuran göçmenlerin aileleri ile birleştirilmesi ile gerçekleşmiştir. AB, II. Dünya Savaşı sonrası dönemde göçü, kendi alt yapı ve ekonomik dağılmışlığını onarmak için desteklemiştir. Ancak sonrasında özellikle 1970’lerde yaşanan petrol krizlerinin neden olduğu ekonomik durgunluk ve işsizlik sonucu Avrupalı ülkeler, dış göçleri sınırlandırmakla kalmayarak sınırlarındaki göçmen işçilerin kendi ülkelerine dönmelerini sağlayacak çeşitli teşvik politikaları oluşturmaya başlamışlardır. Bu dönemde AB için göçün bir güvenlik sorunu haline gelmesi, göçe ilişkin kurumsal düzenlemeleri bundan sonraki $\mathrm{AB}$ gündeminin önemli bir maddesi haline getirmiştir. Bu konuda alınan ilk önemli karar, iç güvenlik konulu (terörizm, polis işleri ve eğitimi, sivil havacılık güvenliği, nükleer güvenlik, doğal afet ve yangından korunma) alanlarda bilgi ve kaynak paylaşımını esas alan ancak ilerde AB'nin göç ve sığınma politikasına zeminini oluşturacak ve yasa dışı göç sorununu da kapsayacak olan ve 1975 yılında Avrupa Birliği Konseyi Roma Zirvesi'nde oluşturulan Trevi Grubu örgütüdür (Karyotis, 2007: 4). Ancak daha sonra aile birleşmeleri yoluyla Avrupa'ya olan göçler devam etmiştir (Hansen, 2003: 27). 1950'li yılların ikinci yarısından petrol krizlerinin yaşandığ 1970'li yıllara kadar olan süreçte yaklaşık 5 milyona yaklaşan bir nüfus Akdeniz ülkelerinden kuzeye doğru göç etmiş, Batı Avrupa'da nüfustaki yabancı uyruklu oranı 1950 'de \%1,3 iken 1965 'de \%3,6, 1990 yılında ise bu oran \%10,3'e çıkmıştır (Subacchi, 2005: 2).

1980’li yıllardan itibaren başlayan küresel ekonomik büyümedeki artışlar da göç eğilimlerinin tekrar hızlanmasına neden olmuştur. Göç eğiliminde yaşanan bu artışın göç alan Avrupa ülkeleri için doğurduğu en önemli sonuç, göçmenlerin emek piyasası için vasıfsız nitelikte iş gücü açığını kapatan bir kitle olarak değil de, sosyal devletin imkânlarından yararlanmaya çalışan, toplumsal düzeni ve refahı tehlikeye sokan ve ülke sinırları için tehdit oluşturan bir kitle olarak algılanmaya başlamasıdır (Güleç, 2015: 84).

Dolayısıyla 1973 yılı sonlarında yaşanan petrol krizi sonrası dönem, Avrupa'da özellikle iş gücü göçüne ve göçmenlerine dair bir algı değişikliğini beraberinde getirmiştir. Bu dönem Avrupa'nın göç algısının tamamen değiştiği ve artık düzensiz ve kontrolsüz göçü önlemeye yönelik politikaların en sert ve yoğun bir şekilde uygulamaya başlandığı bir dönemdir. Böylece Avrupa'da 1970'li yıllara kadar uygulanan açık kapı politikası, ekonomik krizler ve göçmenlerin yol açtığı sosyal olaylar nedeniyle terkedilmiştir.

Avrupa'daki bütünleşme sürecinde genişleme yerine derinleşme politikalarının yoğunlaştığı 1980 sonrası bu dönemde tüm Avrupa genelinde bütünleşmeye şüpheyle yaklaşan söylemlerin arttığını söylemek mümkündür. (Serricchio, 2013: 53). Dolayısıyla özellikle Maastricht Anlaşması ve sonrası dönemde göç ve serbest dolaşım ile ilgili konular, Birlik içerisinde temel tartışma konuları haline gelmiştir. Bu tarihten itibaren AB için göçün bir güvenlik sorunu haline gelmesi, göçe ilişkin kurumsal düzenlemeleri bundan sonraki $\mathrm{AB}$ gündeminin önemli maddesi haline getirmiştir.

AB'nin göç yönetimi ve politikalarında nihayet son dönem AB içerisinde serbest dolaşım hukukunun gelişimi ve 1989 yılında başlayan uluslararası ilişkilerdeki yeni dönemle birlikte yıkılan komünist rejimlerde yaşayan toplumların Batı ülkelerine göç etmesiyle yaşanmıştır. Bu dönemde özellikle Soğuk Savaş sonrası dağılan Doğu Bloku ülkelerinde yaşayan insanların Batı'ya ilticaları, Avrupa'ya yönelik göçün temel kaynağını oluşturmuştur (Hansen, 2003: 27-30). Orta ve Doğu Avrupa'daki emek piyasası ile ilgili sorun ve yetersizliklerin (ücretler, sigorta, iş güvenliği, çalışma koşulları vs.), bu bölgelerden Batıya göçmen akışını sağlayacağı ve bunun 
da Avrupa güvenliğini tehdit edeceği düşüncesi, bu dönemin Birliğe şüpheyle bakan kesiminin savunduğu temel argümanlardan birisi haline gelmiştir (Startin, 2015: 316). Bu dönemde İngiltere siyasetinde de çeşitli parti söylemlerinin, işsizlik ve konut kıtlığı sorunlarının göçmenlerle ilişkilendirilerek şekillendiği görülmektedir (Coulter, 2016: 197).

AB içerisinde göçün bir güvenlik konusu haline gelmesi ve Trevi Grubunun oluşturulması sonrasında konu ile ilgili hükûmetler arası iş birliğinin ilk sonucu Schengen Anlaşması olarak kabul edilebilir. Anlaşma, Trevi'de olduğu gibi hem terörizm hem de yasadışı göçle ilgili hükümler ve iş birliğini içeriyordu (Karyotis, 2007: 5). 1986 yılında imzalanan Avrupa Tek Senedi Anlaşması da Schengen'de sağlanan iş birliğini daha da güçlendirmiş, her iki anlaşma güvenlik endişelerinden ve "istenmeyen" göçün bir tehdit olarak algılanmasından kaynaklanan bir çerçeve oluşturmuştur. Anlaşma, iç sınır kontrollerinin kaldırılması ile ortaya çıkabilecek güvenlik probleminde, dış sınırlarda ise göç sorunu ile ilgili kontrol, düzenleme ve politikalarda ortak hareket etmeyi ve iş birliğini öngörmüştür (Geddes, 2001: 24).

Ortak Pazarın kurulması, Doğu Avrupa'daki ideolojik bölünmenin ortadan kalkması ve yeni güvenlik tehditleriyle mücadele için oluşturulan Trevi Grupları, Sığınma ve Göçle ilgili Özel Gruplar ve Schengen Antlaşması, aslında AB'nin göç politikalarına egemen olan üniter bir güvenlik alanı olma yönündeki hamlelerine işaret etmekle birlikte aynı zamanda $\mathrm{AB}$ göç politikasının gelişimini güvenlik boyutuna net bir şekilde yönlendirmiş, suç, uyuşturucu kaçakçılığı, terörizm ve göç arasında bir devamlılık yaratarak yapılandırmıştır. AB'nin bu tarz bir güvenlik inşası, Avrupa'nın göç konusundaki politikalarını terörizm ve iç güvenlikle ilgili konularla ilişkilendirerek göçün güvenlik unsurlarından biri olarak değerlendirilmesine katkıda bulunmuştur. Kısaca göç artık AB için güvenlik konularından bir hâline gelmiştir. Öyle ki AB için göç, terörizm ve suç birbiriyle ilişkili konulardır (Karyotis, 2007: 5-6).

1989-1998 yılları arasında Avrupa'da iltica başvurusunda bulunanların sayısı yaklaşı 4 milyon düzeyindedir. Bunların \%43'ü bir başka Avrupa ülkesinden gelirken \%35'i Asya, \%19'u ise Afrika kaynaklıdır (Tokgöz, 2006: 16). Ayrıca neo-liberal ekonomi politikaları ile şekillenen bu dönemde insanlar düşük ücretli ve güvencesiz işlerde çalışmaya zorlanmışlar, bu durum gelişmiş ülkelerle gelişmekte olan ve/veya az gelişmiş ülkeler arasındaki ekonomik, siyasi ve toplumsal eşitsizliklerin artmasına neden olmuş ve insanları daha uygun yaşam şartlarına ulaşmak için göç etmeye zorlamıştır (Hammar, 2006; Haas vd., 2020).

1993 yılında yürürlüğe giren Maastricht Anlaşması, göç ve sığınma konularının AB müktesebatına girdiği önemli bir anlaşmadır. Anlaşma ile AB'ye üye olan ülke vatandaşlarına Avrupa vatandaşlığı kavramı getirilmiş ve aynı zamanda Birlik vatandaşlarına üye ülkeler arasında serbest dolaşım hakkı tanınmıştır (Balkır, 2010: 206). Göç ve sığınma yönetimi, Anlaşmanın üçüncü sütunu olan Adalet ve İçişleri alanına alınmıştır. Aynı zamanda Anlaşma ile $\mathrm{AB}$ göç politikaları açısından önemli bir adım niteliğinde olan Trevi Grubu da AB'nin üçüncü sütunu olan Adalet ve İçişleri alanına entegre edilmiştir (Canpolat ve Arıner, 2012: 12).

AB göç yönetiminde 1997'de imzalanan Amsterdam Anlaşması da önemli bir dönüm noktasıdır. AB'nin bir özgürlük, güvenlik ve adalet alanı olduğu belirtilen Anlaşmaya, göç, iltica ve serbest dolaşımla ilgili bir bölüm eklenmiştir. Çok daha önemlisi Anlaşma ile göç ve iltica konuları ile ilgili politika geliştirme sorumluluğu, Maastricht Anlaşması'nda belirlenen devletlerarası bir sütundan (Üçüncü Sütun- Adalet ve İçişleri-) alınarak geleneksel Birlik politikalarının yer aldığı AB Anlaşmaları (Birinci Sütun) bölümüne dâhil edilmiştir (Geddes, 2001: 26). Ayrıca Amsterdam'ın Topluluklaştırması, göç ve ilticanın AB'nin gündemindeki yükselişine işaret etmektedir. Bu durum, Ekim 1999'da Tampere'de düzenlenen ve ortak bir AB göç politikası çağrısında bulunan AB Hükûmet Başkanları Zirvesiyle de doğrulanmıştır (EP, 2019).

Diğer taraftan 11 Eylül terör saldırıları ile birlikte terörizmle mücadeleye verilen yeni vurgu göçün, çok daha fazla düzeyde güvenlik kavramı ile bütünleşik ele alınmasını ve konu ile ilgili literatürde göçün güvenlikleştirilmesi (securitization) olarak ifade edilen kavramsal ve teorik yaklaşımların geliştirilmesini sağlamıştır. 1990'lı yıllarda Buzan ve Waever'ın çalışmaları ile literatüre giren güvenlikleştirme teorisi, 1970'li yıllarda Avrupa'da başlayan ancak 11 Eylül terör saldırıları ile daha belirgin hale gelen güvenlik temelinde göç sorununu açıklamakta oldukça etkili olmuştur (Waever vd., 1993). Önemli kuramsal çalışmaları bulunan Huysmans'a göre göçün güvenlikleştirilmesi, göçün ekonomik, siyasi ve sosyal yönleri dışında güvenlik alanında bir sorun olarak gösterilmesidir (Huysmans, 2000: 758). Bu dönemde göçe yönelik çok daha fazla güvenlik boyutu ile oluşan bu bakış açısı, AB'de sadece Adalet ve İçişleri ile ilgili alanlarla sınırlı kalmayarak, birçok üye devletin göçmenlere yönelik daha kısıtlayıcı politikaları uygulamaya koymalarına neden olmuştur. Örneğin Almanya, istihdam nedeniyle ek göçe izin verecek bir göçmenlik yasa tasarısını, terör saldırıları 1şığında yeniden değerlendirme talepleri baskısıyla askıya almış, kaçak göçmenlere karşı Danimarka, İtalya, Portekiz ve İngiltere 
de zorlu yeni yasalar çıkarmışlardır (Karyotis, 2007, s. 7). Ancak göçün güvenlikleştirilmesi yine Huysmans'a göre AB’nin çok kültürlülük yaklaşımı ile önemli bir tezat teşkil etmekte, özgürlüklerin korunmasını tehlikeye düşürmekte ve ırkçı söylemlere yönelik siyasi oluşumların güç kazanmasına neden olmaktadır (Huysmans, 2006: 46). ${ }^{3}$

Avrupa Komisyonunun Birlik açısından göçün bir sorun haline geldiğinin ve Delegasyonların göçü bu yönde ele almaları gerektiğinin vurgulandığ 12015 yılında yayınlanan “A European Agenda on Migration-Avrupa Göç Gündemi” başlıklı raporundan (EC, 2015) sonraki raporlarda Komisyon, AB için göçü artık bir sorun olarak görmekte ve göç olgusunu bir kriz konusu olarak öne çıkarmaktadır (EC, 2021). Özellikle 2017 yılında yayınlamış olduğu "The EU and the Migration Crisis- AB ve Göç Krizi” başlıklı rapor (EC, 2017) ile AB, göç konusunu bir kriz olarak değerlendirmekte olduğunu, raporda yer alan ve AB'nin bu krizle ilgili neler yaptığının sorulduğu başlıkta ise Komisyonun 2015 yılında ortaya koyduğu göç gündeminde yer alan hususlar temelinde Avrupa göç politikasının hızla ilerlediğini ifade etmektedir.

Son on yıllık zaman dilimine baktığımızda ise Avrupa ve Birlik üyesi ülkeler için siyasi, toplumsal ve ekonomik açıdan önemli çalkantılarla karşı karşıya kaldıkları bir dönemin yaşandığını söyleyebiliriz. Öncelikle dünyada yaşanan iç savaş ve göç dalgasından en çok etkilenen coğrafyaların başında Avrupa yer almıştır. Uluslararası düzeyde en fazla göçün gerçekleştiği bölgesel göç koridorlarının başında, hedef bölgesi Avrupa ülkelerinin yer aldığı Avrupa koridoru gelmektedir. Son on yıllık dönem içerisinde Suriyeli birçok sığınmacı Türkiye ve Kuzey Afrika üzerinden Avrupa'ya akın etmiştir. Ayrıca Rusya’nın Kırım’ı ilhakı, Ukrayna'da yaşanan Maidan olayları, Paris, Berlin, Londra ve Nice'de yaşanan terör olayları, tüm Kıta Avrupa'sında derin yaralar açarken, iklim krizi ve Paris COP-25 Antlaşması birçok ülkede olduğu gibi Avrupa'nın siyasi yönetiminde de büyük değişikliklere neden olmuştur. Tüm bunlara ilave olarak AB'nin geleceğinin sorgulanmasına neden olan İngiltere'nin AB'den ayrılışı ile ilgili yaşananlar da Avrupa ve Birlik üyesi ülkeler açısından son derece önemli gelişmelerdir.

Avrupa'da son dönemde yaşanan bu gelişmelerden ikisi, Brexit ve göç konuları bugün süreci ve etkisi hala devam eden bir özellik taşımaktadır. Üstelik birbirleriye olan neden-sonuç ilişkisi yüzünden her iki başlık, birbirilerinden bağımsız olarak ele alınamayacak bir derinliğe de sahiptir. BM verilerine göre Suriye'de 2011 yılında başlayan iç savaş sebebiyle bugüne kadar 6,6 milyon kişi bu ülkeden başka ülkelere iltica etmiştir. Mültecilerin en fazla geldiği ilk beşte yer alan diğer kaynak ülkeler sırasıyla Venezuella (3,7 milyon) Afganistan (2,7 milyon), Güney Sudan (2,2 milyon) ve Myanmar (1,1 milyon)'dır. BM'nin verileri ile uluslararası mültecilerin toplam sayısının \%68'i bu beş ülke kaynaklıdır (UNHCR, 2020).

Aslında Suriye krizi, Kuzey Afrika coğrafyasında başlayarak süratle Orta Doğu’ya yayılan ve Arap Baharı olarak adlandırılan olaylar dizisinin son halkasıdır. Tunus'ta yolsuzluk ve kötü muameleye tepki olarak 2010 yılı Aralık ayında başlayan olaylar, kısa sürede Mısır, Ürdün, Yemen, Cezayir, Libya ve Bahreyn gibi ülkelere yayılmış, bazı ülkelerde rejimle halkı silahlı çatışmalar seviyesine kadar getirmiş, nihayetinde Suiye'de hala devam eden bir iç savaşa dönüşmüştür (Çakı, 2014: 125).

Suriye krizi, hem bu ülkeden hem de yakın ve bağlantılı coğrafyalardan birçok sığınmacının Türkiye ve Libya üzerinden Avrupa'ya sığınmasına neden olmuştur. Suriye'deki savaşın şiddetlendiği 2015 ve 2016 yılları arasında bu göç akını doruk noktasına ulaşmış, Avrupa'ya doğru gelen göç dalgası AB siyasetinde de bölünmelere yol açmıştır. Ortadoğu'daki Arap Baharı'nın evrimi, Türkiye’ye büyük göç akışı ve aynı tarihlerde yürütülen Türkiye'nin katılım müzakere süreci de $\mathrm{AB}$ kamuoyunda yüksek düzeydeki $\mathrm{AB}$ şüpheciliğinin anlaşılmasında ve artış göstermesinde önemli gelişmeler olmuştur (Utku ve Köroğlu, 2020: 10-11).

Başta Macaristan, Polonya, Danimarka ve Slovakya gibi ülkeler sığınmacılara kapılarını kapatırken, Yunanistan ve İtalya gibi bazı hedef ülkelerde ise bu göç dalgası sosyal yapının değişmesine neden olmuştur. Almanya'nın mülteci krizi dolayısıyla oluşan iş göçünden faydalandığı ve iş gücü açığını, çoğunluğu Suriyeli mültecilerle kapatmaya çalıştığı yorumlanırken (Euronews, 2020-a), Berlin yönetiminin bu kapsamda önemli ve kapsamlı bir entegre politikası izlediği görülmektedir. Diğer taraftan Avrupa'daki birçok ülke de mültecilerle ilgili mevzuatta düzenlemeler yapmak zorunda kalmıştır.

Diğer taraftan Suriye'de 2011 yılında başlayan iç savaş ve Türkiye'ye doğru oluşan göç dolayısıyla Türkiye ile AB arasında 2013 yılında bir Geri Kabul Anlaşması imzalanmıştır. Hem bu anlaşma hem de 2016 yılında her iki taraf arasında varılan Türkiye-AB Mülteci Mutabakatı gereğince Türkiye AB sınırlarına yasal

\footnotetext{
${ }^{3}$ Göçün güvenlikleştirilmesi konusunda ayrıca Bkz; Huysmans (1995, 2002).
} 
olmayan yollardan giriş yapan göçmenleri geri almayı kabul edecek, bu yolla Türkiye'ye geri kabul edilen her bir göçmen karşıllğında geçici koruma kapsamında bulunan birer mültecinin $\mathrm{AB}$ ülkelerine yerleştirilmesi sağlanacaktır (T.C. Dışişleri Bakanlığı, 2020). Her iki taraf arasında varılan mutabakat gereği aynı zamanda Türkiye Cumhuriyeti vatandaşlarının $\mathrm{AB}$ ülkelerinde vizesiz seyahat edebilmeleri için gerekli yasal düzenlemelerin yapılması konusunda Avrupa Komisyonuyla mutabık kalınmışıı. Anlaşma kapsamına İngiltere, İrlanda ve Danimarka dâhil edilmemiş bu üye ülkeler dışındaki diğer tüm AB üyesi ülkeler Anlaşma kapsamına alınmıştır (ABB, 2019).

Komisyonun 4 Ekim 2016 tarihli raporunda vize uygulamasının kaldırılması için öne sürülen 72 kriterin 65'inin Türkiye tarafindan tam olarak yerine getirildiği belirtilmekle birlikte yerine getirilmeyen kriterler içerisinde özellikle terörle mücadele yasasının çok geniş kapsamlı bulunması ve Avrupa standartlarına uygun olarak tekrar gözden geçirilmesi talebi, Türkiye'ye yönelik vize muafiyeti beklentisini önemli ölçüde tehlikeye sokmuştur (EC, 2016-d). Komisyonun gerek 4 Mayıs 2016 tarihli raporunda ve gerekse Haziran ayı içerisinde yayımlanan diğer raporlarında Konsey ve Parlamentoda Türkiye'nin başta terörle mücadele yasasının AB'ye uyumlu hale getirilme talebinin Türkiye tarafindan yerine getirilmediği gerekçe gösterilerek vize serbestisinin $\mathrm{AB}$ kurumlarını memnun edecek bu değişikliklerin gerçekleşmesine bağlı kılındığı ve uygulamaya alınmadığı ifade edilmiştir(EC, 2016-a; EC, 2016-b; EC, 2016-c).

\section{III. İNGILTERE'DE BREXIT SÜRECİ VE GÖÇÜN SÜRECE ETKİSI}

İngiltere, bugünkü AB'nin temel kuruluşlarından biri olan Avrupa Ekonomik Topluluğuna (AET) 1973 y1lında oldukça sancilı bir süreç sonunda üye olduktan sonra AB'nin Schengen ve parasal birlik gibi önemli oluşumlarının dışında kalmayı tercih etmiştir. Aslında üyeliğin ilk döneminden itibaren İngiltere içerisinde, siyasi ve ekonomik bütünleşme ile gücün, Brüksel'deki bürokraside toplanmasından şikayet eden ve AB'nin Schengen ve parasal birlik gibi etkin kurumsal oluşumlarına ve dolayısıyla AB'ye şüpheyle yaklaşan bir kesim de oluşmaya başlamıştır.

Özellikle AB'nin 2004 yılı genişlemesinde çoğu eski Doğu Avrupa ülkesinin Birliğe katılımı ile artan göç ve 2008 küresel finans krizinin ortaya koyduğu özellikle mali politikalardaki uyumsuzluklar, İngiltere içerisinde $A B$ karşıtllğının yaygınlaşmasına neden olan gelişmeler arasında gösterilebilir (Pirro ve Kessel, 2017: 405). İngiltere'nin $A B$ ve göç karşıtı siyasetçisi Nigel Farage'ın liderliğindeki Birleşik Krallık Bağımsızlık Partisinin (UKIP) 1990'lardaki 100 bin oyluk tabanını 2010 yilında 920 bine, 2015'te de 3 milyon 890 bine taşımayı başarması da ülkedeki ana akım siyaseti baskı altına almıştır. Göçmenlik karşıtı söylemin partinin siyasi duruşunda özel bir yere sahip olduğunu Partinin 2015 yılında yayınladığı manifestodan da anlamak mümkündür (UKIP, 2015). 17 milyondan fazla insanı AB'den ayrılmaya ikna ettiği iddia edilen (BBC, 2016-a) Farage, İngiliz siyasetinde göçmenleri hedef alan tek kişi olmasa da eylemleri en radikal ve göç karşııtı söylemi en etkili olanıydı. Partisi, Mayıs 2014'te Avrupa Parlamentosu (AP) seçimlerinde kazandığı başarıyla da çok sayıda milletvekili çıkararak, Brexit'i Avrupa gündemine taşımıştır (AA, 2020).

2013 yılında dönemin Başbakanı David Cameron’un seçimi kaybetmemek uğruna İngiltere'nin AB üyeliğini referanduma götüreceği vaadi (Aljazeera, 2013), az farkla da olsa 2015 yılı Birleşik Krallık seçimlerinde Muhafazakarların tek başına iktidar olmasını sağlamıştır (BBC, 2015). Aslında bir AB taraftarı olan Cameron Kasım 2015 'de göçün sınırlandırılması, ekonomi yönetimi ve ulusal parlemantonun egemenliği ve yetkileri konusunda İngiltere'nin taleplerini içeren mektubunu dönemin Avrupa Komisyon Başkanı Donald Tusk'a göndermiş, Tusk'ın bu talepler doğrultusunda hazırladığı taslak metin Şubat 2016'da toplanan AB Zirvesinde kabul edilmişti (EUCO, 2016). Ancak buna rağmen Cameron, ülkenin AB üyeliği konusunda 23 Haziran 2016 tarihinde referanduma gideceğini açıklamıştır. Cameron'ın amacı aslında İngiltere'nin AB'yi terk etmesi değil, AB'nin reformlar yapmaya zorlanmasıydı (Özkural Köroğlu ve Yüksel Çendek, 2015: 201). İngiliz Başbakan, AB ile vardığı mutabakat çerçevesinde yeniden şekillenecek Birlik üyeliğinin devamı için ülkesinde referandum kampanyası başlatmış, halkı Birlik içerisinde kalma yönünde oy kullanmaya çağırmıştır. İngiliz İşçi Partisi, Liberal Demokratlar, İskoç Ulusal Partisi ve Yeşiller partisi, İngiltere'nin Birlik içinde kalması için kampanya yürüttüler. Cameron referandum kampanyasında $\mathrm{AB}$ 'den ayrılma durumunda karşılaşılacak ekonomik sorunlar üzerinde yoğunlaşırken aynı zamanda göçün kontrol altına alınmasına ilişkin taahhütlerde de bulunmuştur (Powel, 2017: 232). Aslında 2010 yılı seçimleri öncesinde de Cameron'un başaramasa da İngiltere'ye gelen göçmen sayısının düşürülmesi, hatta 1990'lar seviyesine getirilmesi için çaba göstereceğini taahhüt etmesi (The Guardian, 2010), İngiltere'de göçün bir soruna dönüştügünün, Brexit referandumundan daha önceye dayandığını göstermesi açısından önemlidir. 
Brexit kampanya sürecinde Cameron, AB'den ayrılma yanlıları tarafından referandum kampanyasında Türkiye'nin AB'ye üye olacağı belirtilerek oy istendiğini (Cookman, 2016) ancak Türkiye'nin önümüzdeki on yıllarda AB'ye girme ihtimalinin bulunmadığını ve referandumda hayır oyu verecek olanların bu kararını, Türkiye'nin AB üyeliği gibi doğru olmayan gerekçelerle vermemeleri gerektiğini vurgulamıştır (BBC, 2016-b).

Brexit yanlılarının kampanyalarında kullandıkları birkaç temel argümandan birisi göçe karşı sınırların kontrolünün yeniden sağlanması gerekliliği üzerinedir. Göçmen karşıtları ve Brexit yanlıları, AB'nin mülteci sorununu çözememesinden dolayı önemli derecede rahatsızlık duymuş ve AB'nin konu ile ilgili yavaş atılımlarını eleştirmişlerdir. ${ }^{4}$ Brexit sürecinde göçmen krizinin İngiltere'nin AB'den ayrılışına neden olduğunu ifade eden bir çok haberin yazılı ve görsel medyada yer aldığını söyleyebiliriz. ${ }^{5}$ Siyasi arenada da göç konusunun, politikacıların insanların zihinlerini ve tutumlarını kontrol etmek için ihtiyaç duydukları konulardan biri olarak ortaya çıtı̆̆ını söylemek ve bir $\mathrm{AB}$ şüphecisi olan Farage'nın Brexit sürecindeki tutumunu bu kapsamda değerlendirmek mümkündür. Farage gö̈çle ilgili siyasi söylemini, İngiltere'nin AB'yi terk etme arzusunu haklı çıkarmak için etkin bir şekilde kullanmıştır. Cameron'un, İngilizlerin Avrupa konusunda söz sahibi olması gerektiğini ilan ettiğginde Farage, bunun UKIP'in yükselişi için uzun zamandır beklediği bir firsat olduğunu, UKIP'in asıl işinin şimdi başladığını ifade etmiş̧tir (BBC, 2013).

UKIP'in AB'ye yönelik eleştirileri ile göç karşıtı söylemi, Farage'nin Brexit referandumu öncesinde özellikle 2015 yılı Paris saldırıları ile ilgili yaptığı açıklamalarla da anlaşılabilir. Bu açıklamalarda Farage, aslında terör saldırılarının öngürelebilir olduğunu ve bunun kitlesel göç ve çok kültürlü bölünmüşlüğün getirdiği başarısızlıkla çok yakından ilgili olduğunu ifade etmiştir (Mason, 2015).

Uluslararası bir araştırma şirketi olan Ipsos MORI'nin referandumdan hemen önce 21-22 Haziran 2016'da 18 yaş üstü 1592 yetişkinden oluşan temsili örneklem üzerinde yaptığı ankette, "Q5. İngiltere'nin AB üyeliğine iliş̧in referandumda, oyunuzu belirleyecek olan hangi konunun sizin için daha önemli olduğunu düşünüyorsunuz?" sorusuna, katılanların \%32'si İngiltere'ye gelen göçmen sayısındaki artışı karar vermede en önemli sorunlarından biri olarak belirtmişken, \%31'i İngiltere ekonomisi ile ilgili sorunları ve \%16's1 ise İngiltere'nin yasama yetkisi ile ilgili endişeleri göstermiştir (Ipsos MORI, 2016: 3).

UKIP ve o zamanki lideri Farage'ın, göç karşıtı söylemini referandum öncesi Parti programlarına bakarak anlamak mümkündür. Referandumun sonuçlarını, İngiliz seçmenlerinin oylamadan önceki on iki yıl süresince gerçekleşen siyasi tutum ve davranışlarının ayrıntılı bir analizini içeren ve UKIP'in yükselişini daha geniş bağlamda ele alan Harold D.Clarke ve arkadaşlarının çalışması, Brexit taraftarı ve karşıtlarının temel stratejilerinin iki noktada biçimlendiğini, bunlardan ilkinin göç ve ikincisinin ise ekonomik ve güvenlik riskine dayalı konular olduğunu belirtmektedir. Çalışmada yapılan analizin temel bulgusu, referandum öncesi dönemde İngiliz halkının ekonomi, egemenlik ve göç konularında karamsarlığa düştüğü ve bunun bir tezahürü olarak UKIP'e yönelik desteğin arttı̆̆ıdır (Clarke vd., 2017). Ayrıca referandum sürecinde UKIP'in kampanyasını bir siyasal söylem analizi kullanarak inceleyen Utku ve Köroğlu'nun çalışmaları da partinin süreç boyunca göç karşıtı söyleminin, referandumun kazanılmasında etkin olduğunu ancak göçmen karşıtı söyleminin referandum sonrası İngiltere'de ırkçı ve yabancı düşmalığına yol açtı̆̆ını ortaya koymaktadır (Utku ve Köroğlu, 2020).

Referandum sürecinde Alman Şansölyesi'nin izlediği açık kapı politikasının Avrupa'ya kaos getirdiğini, göçün yeterli düzeyde kontrol edilemediği ve dolayısıyla Avrupa kıtasında paniğe yol açtığını, Avrupa göç krizinin ve Brexit tartışmasının daha sonra birbirinden beslendiğini ifade eden çeşitli tartışmalar yaşanmıştır. İngiltere'nin AB'den ayrılışını isteyen Brexit taraftarlarının göç konusunu ayrılışın temel nedeni olarak gösterdikleri bu süreçte, ayrılık taraftarlarının kampanyalarında özellikle Suriyeli mülteciler nedeniyle AB'nin kırılma noktasında olduğu, “AB hepimizi başarısızlığa uğrattı. AB'den kurtulmalı ve sınırlarımızı kontrol altına almalıyız” sloganıyla Brexit sürecini haklılaştırmaya çalıştıkları görülmüştür (Dailymail, 2016).

Son ana kadar başa baş giden referandum yarışından \%48'e karş1 \%52 ile Brexit cephesinin galip çıkması üzerine Başbakan Cameron 11 Temmuz 2016'da Muhafazakar Parti liderliğinden ve Başbakanlık görevinden istifa etmiş yerine ise kabinede İçişleri Bakanlığı koltuğunda oturan ve referandumdan bir ay önce İngiltere'nin AB'de kalması için kampanya yürüten dönemin İçişleri Bakanı Theresa May parti liderliğine seçilmiştir. 13 Temmuz

\footnotetext{
${ }^{4}$ Brexit taraftarlarınca yürütülen kampanya ile ilgili Bkz. Why Vote Leave (2021).

5 Özellikle Brexit yanlısı baskı grubu Leave.eu'nun web sitesi, referandum süreci boyunca bu doğrultuda seçmenlere yönelik medyatik propagandanın merkezi olmuștur. İș adamı Arron Banks tarafından kurulan ve Nigel Farage tarafından desteklenen site, Brexit'e geçișin tamamlanmasından kısa bir süre önce, .eu alanını kaybetmemek için kayıtlarını İngiltere'den İrlanda Cumhuriyeti'ne taşımak zorunda kalmıştır. Şu an askıya alınan ve ulaşılamayan sitenin bu taşınma girişimi de anlaşmazlıkların gölgesinde ve soruşturma altındadır. (Bkz. Independent, 2021).
} 
2016'da da Kraliçe tarafından Başbakan olarak görevlendirilmiştir (CNN, 2016). May, göreve geldikten sonra Brexit sürecini başlatmakta gecikmemiş, Brexit sürecini resmen başlatacak AB Antlaşması'nın 50'inci maddesini ${ }^{6}$ 29 Mart 2017'de işleteceğini açıklamıștır. AB ile zorlu müzakere sürecinin başlamasıyla birlikte May'in hedefi, 2 yıl içinde (29 Mart 2019'a kadar) hem ayrılık koşullarını hem de yeni bir serbest ticaret anlaşmasını müzakere edip sonuca bağlamaktı. Ancak gelişmeler istendiği gibi gerçekleşmemiş ve Başbakan May, parti içindeki bölünmelerle $\mathrm{AB}$ karşısında düştüğü zayıflatıcı konumdan kurtulmak için erken genel seçime giderek güçlü parlamento çoğunluğuyla yeniden hükûmete gelmeyi denemiştir. Fakat May, 8 Haziran 2017'de gidilen erken genel seçimde tek başına iktidara gelememiş, bir azınlık hükûmeti kurmak durumunda kalmıştır. AB ile varılan ayrılık anlaşmasına kendi partisinden birçok kişinin karşı çıması ve bir çok ismin istifa etmesi May'i daha da zor durumda bırakmıştır. May, belirlenen süre içinde $\mathrm{AB}$ ile bir Brexit anlaşmasına varmayı başardıysa da ayrılık anlaşması, İngiltere Parlamentosunda üç kez (15 Ocak, 12 Mart ve 29 Mart) oylanmasına rağmen kabul edilmemiş böylece 29 Mart'ta planan Brexit, önce 12 Nisan'a sonra da 31 Ekim 2019'a ertelenmiştir. May, üç kez reddedilen $\mathrm{AB}$ 'den ayrılık anlaşmasında değişiklikler yaparak yeniden milletvekillerinin onayına sunacağını bildirmiş olmasına rağmen siyasi baskılara dayanamayarak 7 Haziran'dan geçerli olmak üzere Muhafazakar Parti liderliğinden ayrılacağını ve Parti'nin yeni başkanının belirlenmesinin ardından da Başbakanlık görevini bırakacağını açıklamıştır (Euronews, 2019).

Bu istifada ülkede 22 Mayıs 2019'da yapılan AP seçimlerinde Muhafazakar Partinin 5'inci sıraya gerileyerek tarihinin en büyük seçim yenilgisini alması da önemli bir rol oynamıştır. 751 vekil bulunan AP'de, İngiltere 73 sandalye ile temsil edilmekteydi. Yapılan seçimlerde Muhafazakar Parti $(\% 9,1)$ ve İşçi Partisi $(\% 13,8)$ büyük bir yenilgiye uğramış, Brexit referandumunda önemli bir rol oynayan UKIP'ten ayrıldıktan sonra seçimlerden kısa bir süre önce Brexit Partisi'ni kuran Nigel Farage'ın partisi ise önemli bir üstünlük sağlayarak oyların \%31,6'sını almış ve seçimleri ilk sırada tamamlamıştır. İkinci sırayı ise $\% 20$ oyla AB yanlısı Liberal Demokratlar almıştır (BBC, 2019).

May'in görevden ayrılma kararının ardından, Muhafazakâr Parti içerisinde yaklaşık bir buçuk ay süren liderlik yarışı, 23 Temmuz 2019'da sonuçlanmış ve yeni parti lideri olarak, geçmişte Londra Büyükşehir Belediye Başkanlığı ve Dışişleri Bakanlığı görevlerini de yürütmüş olan Boris Johnson seçilmiştir. Johnson, 24 Temmuz 2019'da Theresa May'in istifasını takiben Birleşik Krallık Başbakanlığı görevini üstlenmiştir. Kabinesini Brexit yanlısı isimler ile kuran Boris Johnson, 31 Ekim itibarıyla Brexit'i gerçekleştirme sözü vermiştir (The Telegraph, 2019). Parlamento dengelerinin Brexit sürecini dilediği gibi yönetmesine izin vermeyeceğini gören Johnson, Parlamentoyu 5 hafta tatil kararı almasına rağmen bu karar, Birleşik Krallık Yüksek Mahkemesinden geri dönmüştür. Johnson, bunun üzerine $\mathrm{AB}$ ile yeniden müzakereye başlayarak Brexit anlaşmasında daha önce itirazlara yol açan bazı maddeleri değiştirmeyi başardıysa da Parlamento, çıkardığı yasa ile katı Brexitçi siyasetçiyi AB'den yeni bir erteleme istemeye mecbur bırakmıştır. AB'ye 28 Ekim'de imzasız bir mektupla erteleme talebini ileten Johnson, 29 Ekim'de muhalefet partilerini erken genel seçime ikna etmeyi başarmıştır. 12 Aralık'ta gerçekleşen erken genel seçimlerde aldığı oy ile Johnson, 365 milletvekili çıkararak 650 sandalyeli Avam kamerasından dilediği düzenlemeyi geçirme imkanına kavuşmuştur (AA, 2020). Brexit anlaşmasına ilişkin tasarı, ocak ayı içinde Parlamentonun her iki kanadından hızla geçmiş ve 23 Ocak'ta Kraliçe'nin onayıyla yasalaşmışır. İngiltere, 31 Ocak Cuma günü $\mathrm{AB}$ 'den resmen ayrılarak, ülkenin fiilen $\mathrm{AB}$ üyesi kalacağı ama Birliğin karar süreçlerinde yer almayacağı 11 aylık bir geçiş dönemi yaşamıştır (Euronews, 2020-b). Böylece 2016 yllında yapılan referandum ile alınan Brexit kararı, hiçbir şeyin değişmediği uzun bir geçiş süreci yaşamış, bu süreç boyunca İngiltere'de iki başbakan görevinden istifa etmiş ve ülke iki defa da genel seçimlere gitmek zorunda kalmıştır. Nihayetinde İngiltere'nin $\mathrm{AB}$ ile birlik üyeliğine dayanan bağları, Brexit sürecinin resmiyet kazanmasından neredeyse bir yıl sonra, 31 Aralık 2020 gece yarısı fiilen sona ermiştir.

${ }^{6}$ Avrupa Birliği Antlaşması'nın 50. maddesinde bu imkân şu şekilde düzenlenmiştir:

1- Her üye devlet, kendi anayasal kurallarına uygun olarak Birlikten çekilmeye karar verebilir.

2- Çekilme kararı alan üye devlet, niyetini Avrupa Birliği Zirvesine bildirir. Birlik, söz konusu devletle, Avrupa Birliği Zirvesi tarafindan belirlenen yönlendirici ilkeler ışığında, bu devletin Birlik ile gelecekteki ilişkisinin çerçevesini dikkate alarak, çekilmeye ilişkin kuralları belirleyen bir anlaşmayı müzakere eder ve akdeder. Bu anlaşma, Avrupa Birliğinin İșleyiși Hakkında Antlaşma'nın 218. maddesinin 3. paragrafina uygun olarak müzakere edilir. Anlaşma, Birlik adına, Avrupa Parlamentosunun muvafakatini aldıktan sonra, nitelikli çoğunlukla hareket eden Konsey tarafindan akdedilir.

3- Antlaşmaların ilgili üye devlete uygulanması, çekilme anlaşmasının yürürlüğe girdiği tarihte, bunun gerçekleşmemesi halinde, Avrupa Birliği Zirvesi oybirliğiyle ve ilgili üye devletle mutabık kalarak süreyi uzatmadığı takdirde, 2. paragrafta belirtilen bildirimden iki yıl sonra sona erer. (ABGS, 2011: 30). 


\section{INGILTERE’NIN GÖÇ GÖRÜNÜMÜ VE GÖÇ SORUNU ALGISI}

2019 yılında Avrupa'daki toplam göçmen sayısı 82,3 milyon kişidir. Bu göçmenlerin \%11,5'i İngiltere'de yaşamaktadır. Bu oran İngiltere'de yüksek ölçüde bir göçmen sayısına işaret etmektedir. Dolayısıyla buna göre İngiliz halkının Brexit'e taraf olmasının göç ile ilgili dayandığı bir temel vardır. Ancak bunun emek piyasası ile ilgili olması çok muhtemel değildir. Öyleyse İngiliz halkının gerek Brexit taraftarlarınca gerekse karşıtlarınca dile getirilen göç karşıtlığının nedeni nedir? Bu durum göç ile oluşan toplumsal değişimin bir sonucu olarak yaşanılan farklılaşmanın getirdiği endişelerle açıklanabilir. Bu endişeler, güvenlik ve suç gibi unsurlarla, göçmenlerin sağlık ve eğitim gibi çeşitli sosyal yardım hizmet taleplerinin getirdiği olumsuz etkilerle veya bugün tüm Avrupa ülkelerini tehdit eden milliyetçilik dalgasının oluşturduğu politik etkilerle ortaya çıkmaktadır.

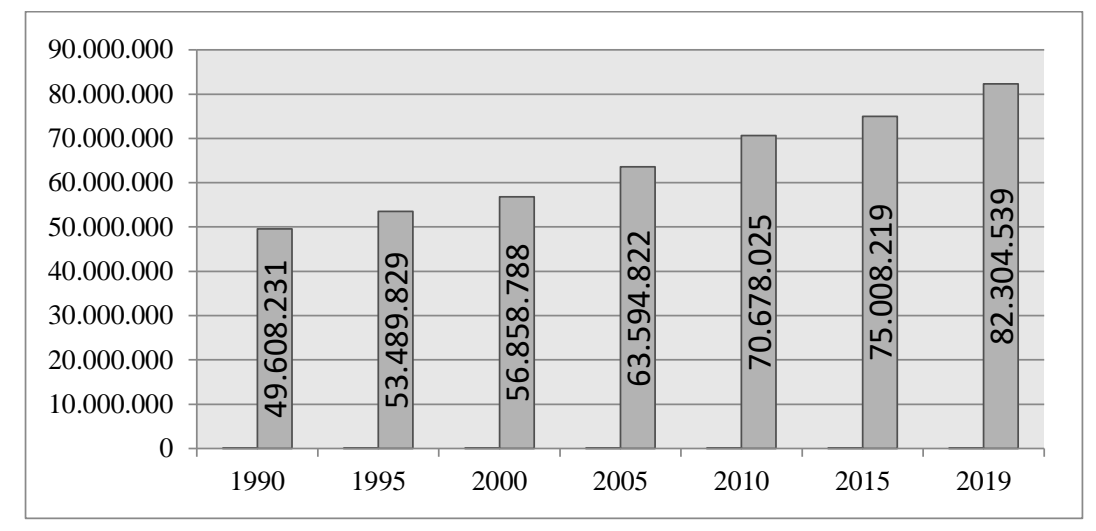

Grafik 1. Avrupa'daki Toplam Göçmen Sayıları (1990-2019)

Kaynak: UNDESA, 2019 verilerinden elde edilmiştir.

BM Ekonomik ve Sosyal İşler Daire Başkanlığı (United Nations, Department of Economic and Social Affairs- UNDESA) verilerine göre Avrupa ülkelerinde bulunan göçmen sayıları, Grafik 1'de de gösterildiği gibi 1990 yılında 49,6 milyon düzeyindeyken 2019 yılında 82,3 milyona yükselmiştir. Böylece 1990 ile 2019 yılları arasında Avrupa'daki göçmen sayısında \%66 oranında bir artış yaşanmıştır. Diğer taraftan UNDESA'nın verilerinden elde edilen Tablo 1'deki rakamlara göre ise İngiltere'de yaşayan yabancı sayısı 2019 yılında toplam 9,5 milyon kişidir. Bu toplam Avrupa'da yaşayan göçmen sayısının \%11,5'idir. Bu sayı aynı zamanda İngiltere yerleşik nüfusunun da \%14'üne denk gelmektedir. İngiltere'de yaşayan AB ülkesi vatandaşların sayısı ise aynı yıl için 3,3 Milyon kişiye (İngiltere toplam nüfusunun \%5'i) yakındır.

Tablo 1. Birleşik Krallık’ta Yaşayan Yabancıların Sayısı (1990-2019)

\begin{tabular}{|c|c|c|c|c|c|c|c|c|c|}
\hline & 1990 & 1995 & 2000 & 2005 & 2010 & 2015 & 2019 & $\begin{array}{c}\text { İngiltere } \\
\text { Nüfusu } \\
\text { İçerisindeki } \\
\text { Payı } \\
\text { (2019- \%) }\end{array}$ & $\begin{array}{c}\text { Artış Oranı } \\
(1990-2019) \\
(\%)\end{array}$ \\
\hline $\begin{array}{l}\text { Genel } \\
\text { Toplam }\end{array}$ & 3.650 .286 & 4.155 .293 & 4.730 .165 & 5.926 .156 & 7.119 .664 & 8.411 .569 & 9.552 .110 & 14 & 162 \\
\hline $\begin{array}{l}\text { AB üye } \\
\text { Ülke } \\
\text { Toplamı }\end{array}$ & 1.345 .000 & 1.383 .211 & 1.444 .708 & 1.926 .967 & 2.446 .445 & 2.915 .695 & 3.311 .062 & 5 & 146 \\
\hline $\begin{array}{l}\text { AB-8* } \\
\text { Ülke } \\
\text { Toplamı }\end{array}$ & 97.275 & 97.718 & 99.814 & 502.626 & 805.622 & 1.108 .405 & 1.258 .705 & 2 & 1194 \\
\hline
\end{tabular}

* Bu ülkeler, 1 Mayıs 2004'te AB'ye katılan 8 Orta ve Doğu Avrupa ülkesi olan; Çek Cumhuriyeti, Estonya, Macaristan, Letonya, Litvanya, Polonya, Slovakya ve Slovenya'dır.

Kaynak: UNDESA, 2019 verilerinden elde edilmiştir.

Bu rakamlar İngiliz Ulusal İstatistik Ofisinin 2019 yılı için hazırladı̆̆g, İngiltere'deki nüfusun doğdukları ve uyruğunda bulundukları ülkelere göre elde edilen istatistikleri içeren rapordaki bulgularla da hemen hemen aynıdır. 2019 yılı için \%14 düzeyinde gerçekleşen yerleşik nüfusun yurtdışı doğumlularının oranı 2004 yılında \%8,9 iken 2014 yılında \%13'tür UNDESA, 2019; ONS, 2019, s. 2). Bu durum bize 1990-2019 y1lları arasında 
İngiltere'de yerleşik nüfustaki yabancı sayısının gittikçe arttığını ve bu artış oranının \%162 düzeyinde gerçekleştiğini göstermektedir.

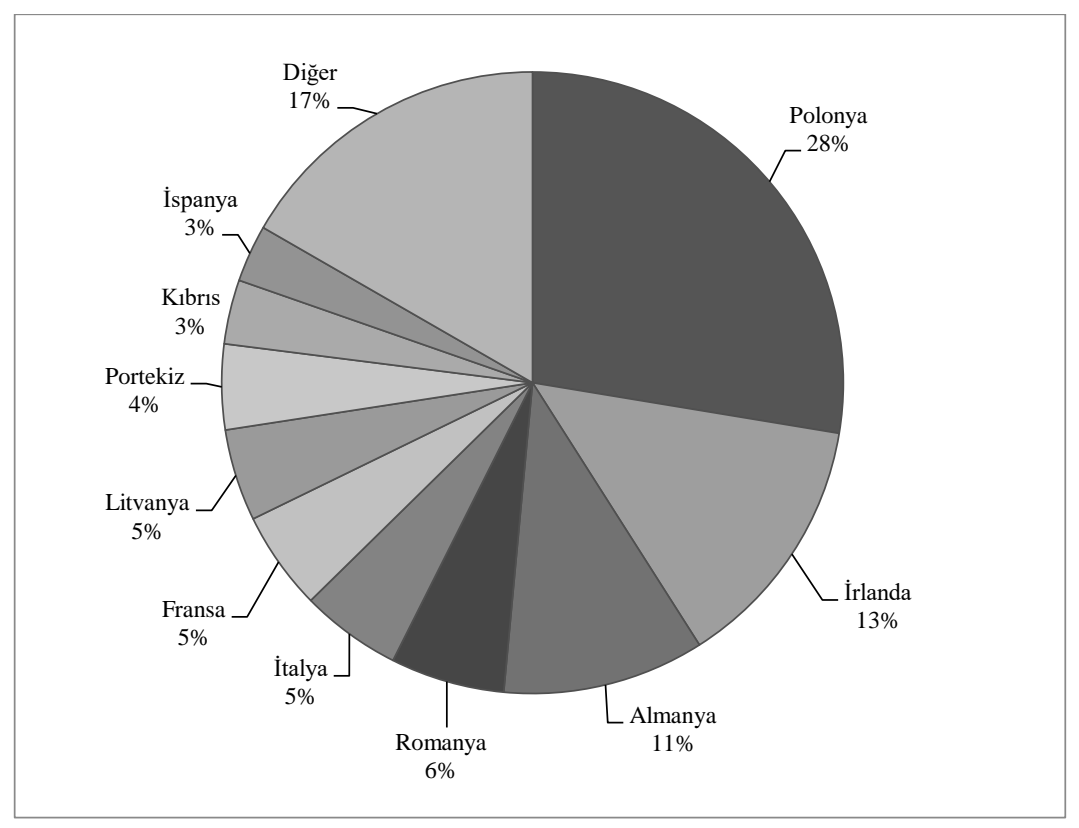

Grafik 2. İngiltere'deki AB Vatandaşlarının Menşe Ülkelerine Göre Payı (2019 - \%)

Kaynak: UNDESA-2019 verilerinden elde edilmiştir.

Grafik 2'de gösterildiği gibi 2019 yılı verileri ile İngiltere' de yaşayan 3,3 milyon AB vatandaşının en fazla sayıda olanı 914.022 kişi ve \%28 oranla Polonyalılardır. Sonrasında İrlanda (442.796 kişi), Almanya (347.634 kişi) ve Romanya (196.503 kişi) gelmektedir. Diğer taraftan BM istatistiklerine göre İngiltere'de Brexit sürecinde de Brexit taraftarlarınca önemli bir sorun olarak dillendirilen AB-8 grubu ülke uyruklu olanların sayısı 2019 yılında 1,3 milyona (toplam nüfusa oranı \%2) ulaşmıştır. Ayrıca bu sayı içerisinde tüm AB üyesi ülke vatandaşları kapsamında olduğu gibi AB-8 grubu kapsamında da Polonya uyruklu olanlar ilk sırada gelmektedir. ${ }^{7}$ (Bu sayı İngiltere'de yaşayan ancak İngiltere'de doğmamış toplam yabancı nüfusun \% 9,6'sını oluşturmaktadır). Polonya uyrukluların sayısı, İngiltere'deki toplam yabancı nüfus içerisinde de Hindistan'dan (917.686 kişi toplam yabancı nüfusun \%9,6) sonra ikinci sırada gelmektedir. İngiltere'deki tüm yabancıların sayılarının yer aldığı genel toplam içerisinde üçüncü sırayı Pakistan uyruklular (605.016 kişi - toplam yabancı nüfusun \%6,3), dördüncü sırayı İrlandalılar (442.796 kişi - toplam yabancı nüfusun \%4,6) ve beşinci sırayı ise Almanlar (347.634 kişi - toplam yabancı nüfusun \%3,6) almaktadır. Ayrıca tabloya göre İngiltere'de 2019 yılı verileri ile AB üyesi ülke vatandaşı olan (İngilizler hariç) ikamet edenlerin sayısı (3.311.062 kişi), AB üyesi olmayan vatandaşlardan (6.241.048 kişi) daha düşüktür. Bu oran daha önceki dönemlerde AB üyesi ülke vatandaşlarının sayıları lehine bir durum göstermekte idi. Örneğin 2013-2014 yılları arasında Birleşik Krallık'ta AB vatandaşı olan (İngilizler hariç) yerleşiklerin sayısı, AB üyesi olmayan vatandaşlardan (2.406.000'e kıyasla 2.938.000) daha yüksekti (ONS, 2015: 3).

\footnotetext{
${ }^{7}$ Ulusal İstatistik Ofísine göre İngiltere ve Galler’de en çok konuşulan ikinci dil Lehçedir. (Bkz. ONS, 2011)
} 


\begin{tabular}{|c|c|c|}
\hline & $\begin{array}{l}\text { BŞEÜ Sosyal Bilimler Dergisi } \\
6(2), 484-503,2021\end{array}$ & $\begin{array}{r}\text { BSEU Journal of Social Sciences } \\
\text { https://doi.org/10.33905/bseusbed.1027257 }\end{array}$ \\
\hline $\begin{array}{l}\text { BILECIKSEYYHEDEB ER } \\
\text { ONIVERSITE }\end{array}$ & $e-I S S I$ & 2548-088X (https://dergipark.org.tr/tr/pub/bseusbed) \\
\hline
\end{tabular}

Tablo 2. Birleşik Krallık’ta Yaşayan AB-8 Ülkeleri, Türkiye ve Suriyeli Yabancıların Sayısı (1990-2019)

\begin{tabular}{lrrrrrrr}
\hline Ülke/Ylllar & $\mathbf{1 9 9 0}$ & $\mathbf{1 9 9 5}$ & $\mathbf{2 0 0 0}$ & $\mathbf{2 0 0 5}$ & $\mathbf{2 0 1 0}$ & $\mathbf{2 0 1 5}$ & $\mathbf{2 0 1 9}$ \\
\hline Polonya & 71.908 & 64.757 & 58.696 & 328.865 & 537.859 & 804.877 & 914.022 \\
\hline Litvanya & 1.182 & 2.675 & 4.214 & 52.001 & 139.497 & 139.497 & 158.413 \\
\hline Slovakya & 1.431 & 3.236 & 5.097 & 31.435 & 33.115 & 42.349 & 48.091 \\
\hline Letonya & 1.160 & 2.623 & 4.132 & 30.230 & 31.846 & 40.726 & 46.248 \\
\hline Macaristan & 12.192 & 12.352 & 12.721 & 30.132 & 31.742 & 40.593 & 46.097 \\
\hline $\begin{array}{l}\text { Çek } \\
\text { Cumhuriyeti }\end{array}$ & 8.523 & 10.086 & 11.819 & 23.471 & 24.725 & 31.619 & 35.906 \\
\hline Slovenya & 334 & 756 & 1.192 & 1.555 & 1.638 & 2.094 & 2.377 \\
\hline Estonya & 545 & 1.233 & 1.943 & 4.937 & 5.200 & 6.650 & 7.551 \\
\hline $\begin{array}{l}\text { AB-8 Ülke } \\
\text { Toplamı }\end{array}$ & $\mathbf{9 7 . 2 7 5}$ & $\mathbf{9 7 . 7 1 8}$ & $\mathbf{9 9 . 8 1 4}$ & $\mathbf{5 0 2 . 6 2 6}$ & $\mathbf{8 0 5 . 6 2 2}$ & $\mathbf{1 . 1 0 8 . 4 0 5}$ & $\mathbf{1 . 2 5 8 . 7 0 5}$ \\
\hline Türkiye & 25.947 & 38.795 & 52.296 & 68.300 & 71.951 & 92.014 & 104.491 \\
\hline Suriye & 2.761 & 3.366 & 4.028 & 6.191 & 6.521 & 8.339 & 9.469 \\
\hline
\end{tabular}

Kaynak: UNDESA-2019 verilerinden elde edilmiştir.

BM istatistiklerinden elde edilen Tablo 2'de de yer alan rakamlara göre İngiltere'de AB-8 grubu ülke vatandaşlarının sayısında, bu ülkelerin 2004 yılında AB üyeliğine kabulünden sonra önemli bir artış yaşanmıştır. Örneğin İngiltere'deki Polonyalıların sayısı 2000 yılında 58.696 iken 2005 yılında 328.865, 2010 yılında 537.859 ve 2015 y1lında ise 804.877 kişiye yükselmiştir. Tablo 1'de gösterildiği gibi AB-8 ülkelerinin 1990-2019 döneminde İngiltere nüfusundaki artış oranı \%1194'tür. Bu, İngiltere'deki tüm AB üyesi ülke vatandaşlarının sayısında aynı dönemdeki \%146'lık artış oranı düşünüldüğünde oldukça önemli bir artış yüzdesidir.

BM'nin ve İngiliz Ofisinin ortaya koyduğu rakamlar, son yirmi dokuz yıllık dönemde gerek İngiltere dışı doğumlu olan nüfusta gerekse İngiltere'deki yabancı uyrukluların sayısında önemli ölçüde artışın yaşandığını göstermektedir. Bu artışta eski Doğu Avrupa ülkelerinin bir kısmının AB'ye alınması ile başlayan süreçte bu ülkelerden kaynaklı göç dolayısıyla yaşanan hareketlilik dikkat çekmektedir. İngiltere'de yaşayan yabancı uyruklularda 2004 yılında Birliğe katılan Polonya ve Litvanya, 2007 yılında Birliğe katılan Romanya gibi eski Doğu Avrupa ülkelerinin bulunuşu, İngiliz halkının Brexit sürecini desteklemesinde etkili olan göç sorununu ve endişesini doğrulamaktadır (Özerim, 2017: 89-90).

Diğer taraftan Tablo 2'de görüldüğü gibi BM'nin ortaya koyduğu rakamlardan Brexit sürecinde göç ile ilgili dile getirilen bir diğer argüman olan İngiltere'ye Türkiye üzerinden Suriye kaynaklı göçün getireceği olumsuzluklar üzerine kurulu söylemin çok gerçekçi olmadığı anlaşılmaktadır. Zira belirtilen dönem içerisinde Suriye ve Türkiye'den gelen yabancı sayısında bir artış yaşanmış olmasına rağmen 2019 yılında elde edilen toplam göçmen sayısının İngilizleri ekonomik ve toplumsal yönüyle korkutacak ölçüde olmadığı anlaşılmaktadır. Bu durum Brexit yanlılarınca kullanılan göç ile ilgili endişelerin, Türkiye ve/veya Suriye kaynaklı değil, Avrupa ülkelerinden özellikle AB ve AB içerisinde eski Doğu Avrupa'nın Birliğe son katılan ülkelerinden kaynaklandığı anlaşılmaktadır. İngiltere'nin AB'den ayrılışının en önemli gerekçelerinden birisi göçtür. Ancak bu göçün kaynağ 1 Avrupa dişı değil, özellikle AB üye ülkelerindendir.

Tablo 3. Avrupa'da bulunan Birleşik Krallık Vatandaşlarının Sayısı (1990-2019)

\begin{tabular}{lrrrrrrr}
\hline & $\mathbf{1 9 9 0}$ & $\mathbf{1 9 9 5}$ & $\mathbf{2 0 0 0}$ & $\mathbf{2 0 0 5}$ & $\mathbf{2 0 1 0}$ & $\mathbf{2 0 1 5}$ & $\mathbf{2 0 1 9}$ \\
\hline Doğu Avrupa & 6.209 & 9.555 & 13.345 & 34.081 & 55.208 & 66.973 & 89.305 \\
\hline Kuzey Avrupa & 307.838 & 252.340 & 269.879 & 355.502 & 409.979 & 439.894 & 478.822 \\
\hline Güney Avrupa & 171.781 & 162.934 & 186.679 & 315.521 & 439.076 & 426.967 & 435.639 \\
\hline Batı Avrupa & 293.945 & 312.027 & 330.939 & 359.065 & 383.619 & 389.405 & 419.900 \\
\hline Toplam Avrupa & $\mathbf{7 7 9 . 7 7 3}$ & $\mathbf{7 3 6 . 8 5 6}$ & $\mathbf{8 0 0 . 8 4 2}$ & $\mathbf{1 . 0 6 4 . 1 6 9}$ & $\mathbf{1 . 2 8 7 . 8 8 2}$ & $\mathbf{1 . 3 2 3 . 2 3 9}$ & $\mathbf{1 . 4 2 3 . 6 6 6}$ \\
\hline
\end{tabular}

Kaynak: UNDESA 2019 verilerinden elde edilmiştir.

Brexit sürecinin sonlanması ve İngiltere'nin AB'den ayrılması ile gündeme gelecek sorunlardan bir diğeri ise $A B$ ülkelerinde bulunan İngiliz vatandaşlarının durumu ile ilgilidir. Brexit şu anda İngiltere'de yaşayan Avrupalı vatandaşlarla $A B$ genelinde yaşayan İngiliz vatandaşlarının yasal statüsünü bozmaktadır. Sorun 
müzakere sürecinde çözülmüş görünmekle birlikte esasen mevcut göçmenlerin kayıtlarını ilgili ülkelerde yapmalarına ve daimi ikamet elde etmelerine izin vereceği düşünülmektedir. BM istatistiklerine ve bu istatistiklerden elde edilen Tablo 3'e göre, 1990-2019 döneminde Avrupa'daki İngiliz vatandaşlarının sayısında artış yaşanıyor olması yanında bu durum oldukça düzenli ve istikrarlı bir yönelim izlemektedir. Avrupa'da bulunan İngilizler, toplam Avrupa'daki göçmenlerin \%1,73’ünü oluşturmaktadır. En son 2019 yılı verileri ile Avrupa'da en fazla Kuzey Avrupa ülkelerinde bu bölgede ise en fazla İrlanda'da (293.061 kişi) İngiliz vatandaşının bulunduğu görülmektedir. Güney Avrupa'da İspanya (302.020 kişi), Batı Avrupa'da Fransa (176,672 kişi) ve Doğu Avrupa'da ise Polonya (89.305 kişi) İngilizlerin en fazla bulunduğu ülkelerdir.

AB yasalarına göre, üye ülkeler karşılıklı serbest dolaşıma tabidir, yani birbirlerinin vatandaşlarına vize zorunlulukları, çalışma izinleri, kotalar veya diğer göçmenlik kısıtlamaları getiremezler. $\mathrm{Bu}$ durum, AB vatandaşlarının herhangi bir AB üyesi ülkede yaşama ve çalışma özgürlüğüne sahip olduğu anlamına gelmektedir. Yukarda Tablo 1'de, 1990'dan itibaren AB ülkelerinden İngiltere'ye net göçün artış gösterdiği görülmektedir. Bu artış büyük ölçüde 2004'te AB'ye katılan sekiz eski Doğu Avrupa ülke (AB-8) grubundan gelen ve düşük vasıflı göçmenlerden kaynaklanmaktadır. AB-8 grubunun katılımı sonrası İngiltere'ye bu grup ülke kaynaklı göçün keskin bir şekilde arttığı Tablo 1'de dikkat çekmektedir.

Emek için hareket özgürlüğü AB'nin temel ilkelerinden biridir ve bu, futbolcusundan meyve toplayıcısına, doğmadıkları bir AB ülkesinde yaşayan milyonlarca AB vatandaşını etkilemektedir. Eski Doğu Avrupa ülkelerinin Birliğe alınmasıyla yaşanan iş göçü, yeni gelen işçilerin esnek çalışma koşullarına uyumu ve daha düşük ücretle çalışma yönündeki istekleri, geldikleri AB ülkesinde mavi yakalı işçilerin tepkisine neden olmuş ve bu durum İngiltere'de işçi kesiminin büyük bir kısmının Nigel Farage'ın UKIP’ine yönelmelerine yol açmıştır. Tepkinin bir diğer nedeni de İngiltere'deki göçmenlerin sosyal yardım talep etme hakları ile ilgilidir (Boyle, 2018).

Ancak İngiltere'yi Brexit sürecine götüren, taraftarlarınca ifade edildiği gibi göçün ekonomik yönüyle İngiltere'deki emek piyasasını olumsuz yönde etkileyeceği şeklindeki argüman, çok da doğru görünmemektedir. Zira İngiltere, Birlik üyesi ülkeler arasında iş gücü piyasasındaki hareketliliği kolaylaştıran ve kısıtlamaları kaldıran Schengen Anlaşmasına taraf değildir. İngiltere'nin Schengen'e taraf olmayışı, hem ülke içinde AB karşıtlığının bir göstergesi iken hem de Brexit taraftarlığının emek göçü ile ilgili olmadığını, yani İngiltere'nin AB'den ayrılış kararında göçün emek piyasası ile ilgili yönünün ve etkisinin olamayacağını göstermektedir. Zaten bu durum Brexit karşıtı olan kesim içerisinde göç karşıtı olanların varlığı ile de kendini belli etmektedir. Göçmenlerin ülke nüfusuna eklenmesi, doğum oranlarındaki artış veya ölüm oranlarında meydana gelen azalma gibi nüfus miktarını arttırır. İngiltere'nin son yüz yıl içerisinde nüfusu \%50 oranında artmıştır. Ancak işsizlik oranı kaçınılmaz olarak yukarı yönlü bir seyir izlememiştir.

İngiltere'deki önemli araştırma merkezlerinden Ekonomik Performans Merkezinin (Centre for Economic Performance - CEP) hazırladığı rapor, İngiltere'deki AB göçmenlerinin yaş ortalamasının genellikle daha genç olduğunu belirtmektedir. Buna göre çalışma çağındaki nüfus içerisinde İngilizlerin yaş ortalaması 40, tüm AB göçmenlerinin yaş ortalaması 38 ve AB-8 grubu ülke vatandaşlarının yaş ortalaması ise 34'tür. Rapora göre $A B$ göçmenleri daha genç ve aynı zamanda daha eğitimli oldukları için İngilizlere göre iş bulma olasılıkları daha yüksektir. Göçün, çalışan veya iş arayan toplam insan sayısını artırdığ taraftarlarınca savunulduğu gibi İngiltere'deki işçilerin artan iş rekabeti karşısında zarar görme olasılığının yüksek olacağı iddiası, varılacak muhtemel sonuçlardan birisidir. Ancak bunun bir emek yanılgısı olduğunu belirten rapor, göçmenlerin mal ve hizmet tükettikleri ve bu artan talebin daha fazla istihdam firsatı yaratılmasına yardımcı olduğunu ortaya koymaktadır. Rapor ayrıca göçmenlerin İngiliz işçileri tamamlayan becerilere sahip olabileceğini ve dolayısıyla göçün ekonomik etkisinin İngiliz işçiler için olumlu ya da olumsuz sonuçlarını ortaya koymak amacıyla mutlaka ampirik kanıtlara ihtiyaç duyulacağını belirtmektedir (Wadsworth vd., 2016). 


\begin{tabular}{|c|c|c|}
\hline & $\begin{array}{l}\text { BŞEÜ Sosyal Bilimler Dergisi } \\
6(2), 484-503,2021\end{array}$ & $\begin{array}{r}\text { BSEU Journal of Social Sciences } \\
\text { https://doi.org/10.33905/bseusbed.1027257 }\end{array}$ \\
\hline $\begin{array}{l}\text { BILECIK SEYHEDEBALI } \\
\text { UNIVERSITES }\end{array}$ & $e-I S S \Lambda$ & 2548-088X (https://dergipark.org.tr/tr/pub/bseusbed) \\
\hline
\end{tabular}

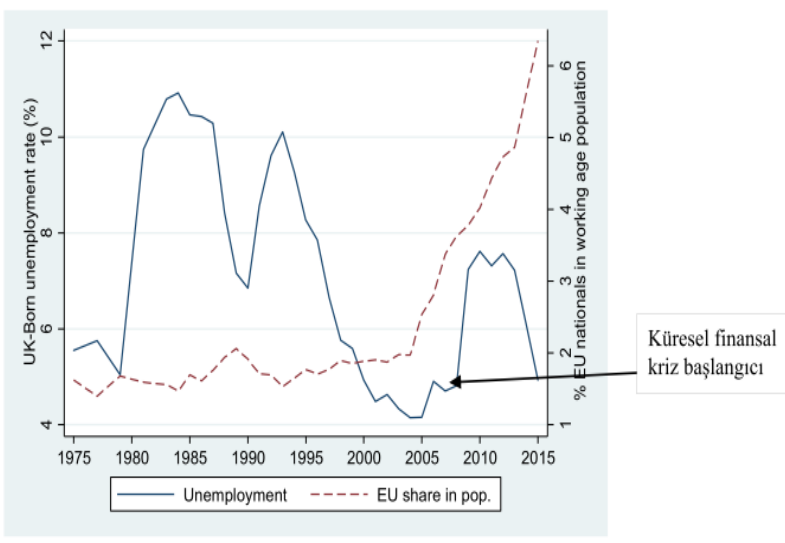

Grafik 3. İngiltere Doğumlularla AB Ülkelerinden Göçenlerin İşsizlik Oranı (1975-2015)

Kaynak: (Wadsworth vd., 2016: 6)

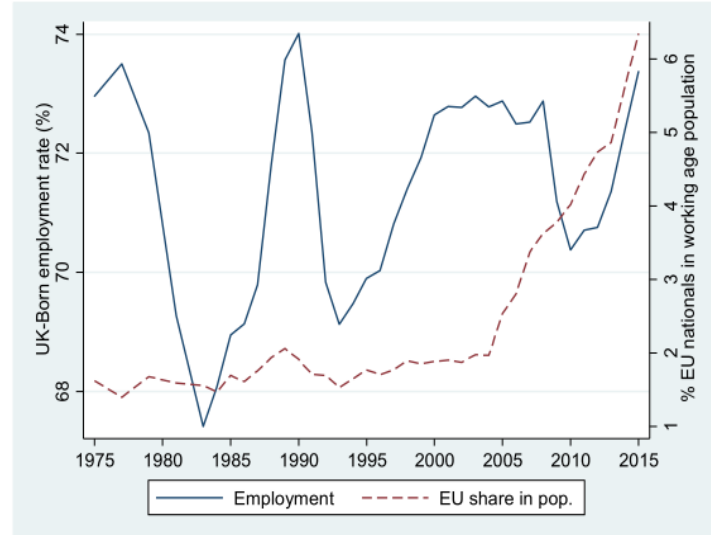

Grafik 4. İngiltere Doğumlularla AB Ülkelerinden Göçenlerin İstihdam Oranı (1975-2015)

Kaynak: (Wadsworth vd., 2016: 7)

Grafik 3 ve 4'de İngiltere'de doğan bireylerin işsizlik ve istihdam oranları ile AB ülkelerinden gelen göç eğilimleri gösterilmektedir. Grafik 3'de AB'ye olan göçün hızla yükseldiği 2004 sonrası dönemde İngilizlerin işsizlik oranlarının önce yükseldiği fakat sonrasında göç artmaya devam ettiği halde işsizlik oranlarının çok düşük düzeylere gerilediği görülmektedir. Benzer bir görüntü grafik 4'de İngiltere doğumlu çalışanların istihdam oranlarında da görülebilir. 1975-2015 yılları arasında İngiltere doğumlu iş̧̧ilerin istihdam oranı ekonomik döngü ile yukarı ve aşağı gitmektedir. Ancak $A B$ göçünün arttı̆̆ son dönemde istihdam oranın da arttığı görülmektedir. İstihdam oranı, neredeyse önceki kazanımlarının zirve seviyelerine geri dönmüştür (Wadsworth vd., 2016: 6-7).

Raporda elde edilen bulgular, İngiltere'nin göçün büyük artış gösterdiği bölgelerinin, İngiliz işçilerin işlerinde ve ücretlerinde daha fazla düşüş oluşturmadığını da göstermektedir. Rapor, 2008'den sonra ücretlerde meydana gelen düşüşlerin göçten ziyade küresel finansal krizden ve zayıf bir ekonomik iyileşmeden kaynaklandığını belirtmektedir. Ayrıca daha az vasıflı İngiliz iş̧̧ilerin ücretlerinde ve iş bulma olanaklarında meydana gelen azalmada göçün etkisinin çok düşük düzeyli olduğunu; elde edilen ampirik bulguların daha az eğitimli İngiltere doğumlu iş̧̧ilerin ücret ve işsizlik değişikliklerinin, AB ülkelerinden İngiltere'ye olan göçteki değişikliklerle çok az korelasyon gösterdiğini ortaya koymaktadır. Ayrıca İngiltere'deki AB göçmenleri vergi ve sosyal hizmetlerin kullanımından daha fazla vergi ödemeleri onların bütçe açığının azaltılmasına yardımcı oldukları anlamına da gelmektedir. ${ }^{8}$

Brexit'in gerçekleşmesi ile İngiltere artık göç politikaları ile ilgili AB'nin kurumsal karar ve kurallarına tabi olmayacak, kendi sınırlarının kontrolünü sağlayarak kendi göç sistemini oluşturmakta özgür olacaktır. Dolayısıyla burada önemli olan nokta İngiltere'nin nasıl bir göç politikası izleyeceği ve Brexit'in diğer AB üyesi ülkelerde var olan serbest dolaşımı nasıl etkileyeceği sorunudur. İngiltere, Brexit'in uygulamada gerçekleşmesi ile halihazırda Avrupalı olmayanlara yönelik uyguladığı politikaya benzer bir şekilde AB vatandaşlarına da çalışma ve oturma izni kriterlerini uygulayarak ana karaya olan göçü kısıtlamayı amaçlamaktadır. Brexit sonrası İngiltere göç sistemi için düşünülen ve önerilen yöntemlerden biri, $\mathrm{AB}$ vatandaşlarının yeteneklerine göre çalışma izinleri için düşük vasıflı - yüksek vasıflı ayırımına gidilebileceğidir. Düşük vasıflı işçiler, iki ya da üç yıl süren geçici izinler için uygun görülürken, ikamet için uygun olamayacaklardır. Yüksek vasıflı iş̧iler için ise beş yıllık çalışma izni almaya hak kazandıkları takdirde oturma izni için başvuru olanağına sahip olabileceklerdir. Ancak İngiltere'nin oluşturacağı göç politikasında, ekonomisinin $\mathrm{AB}$ ülkeleri emek gücüne olan bağımlılığından kurtarmanın çok kolay olamayacağını bilmesi gerekir (King ve Flynn, 2018).

\footnotetext{
${ }^{8}$ İngiltere'de göçün emek ve ücretler üzerindeki etkisini inceleyen çok sayıda araştırma vardır. Bu araştırmaların vardığı sonuç, İngiltere'de göçmen sayısındaki büyük artışın, İngiliz çalışanların iş gücü ve ücret beklentilerine önemli ölçüde zarar vermediğidir. Bkz. Wadsworth (2015); Portes (2016); Springford vd., (2016), Dustmann vd., (2005).
} 


\section{SONUC}

Sancılı bir başvuru sürecinden sonra 1973 yılında İrlanda ve Danimarka ile birlikte Birliğe kabul edilen İngiltere, iç politika bağımsızlı̆̆ı ve bazı egemenlik haklarının devri konularında $A B$ için her zaman sorun oluşturmuştur. İngiltere AB üyeliği boyunca Schengen ve parasal birlik konularında olduğu gibi AB'nin yürürlüğe koyduğu birçok ulus üstü ve hükûmetler arası anlaşmalardan kendini ayrıştırmayı başarmıştır. Brexit, bu ayrışmanın en kalıcısıdır.

Brexit sürecinde göç konusunun yoğun bir şekilde propaganda aracı olarak kullanıldığı görülmüştür. Her iki taraf da göçün İngiltere için önemli bir sorun olduğu konusunda aynı kanaattedir. Ancak Brexit taraftarlarınca AB'den ayrılış İngiltere'ye gelen göçü azaltacaktır.

İngiltere'de son otuz yıllık zaman içerisinde göçün artış gösterdiğini, özellikle 2004 yılı sonrası dönemde bu artışın eski Doğu Avrupa ülke kaynaklı çok daha yüksek düzeyli gerçekleştiğini söyleyebiliriz. Göç kaynaklı endişe, İngiliz halkının AB üyeliğini sorgulan ve etkileyen faktörler içerisinde önemli bir düzeye ulaştığında ise İngiltere'nin AB'den ayrılış süreci başlamış ve İngiltere, daha bağımsız bir göç politikası için önemli bir güç elde etmiştir.

Bu çalışmada kullanılan çeşitli istatistiksel veriler ve araştırmalar göstermektedir ki, İngiltere için mülteci krizinin oluşturduğu endişenin kaynak coğrafyası, Suriye gibi Avrupa dışı coğrafyalar değil Avrupa coğrafyasıdır. $\mathrm{Bu}$ veriler aynı zamanda göçün İngiltere için ekonomik olmaktan ziyade sosyolojik ve siyasi gerekçelerle açıklanabilir olduğunu da ortaya koymaktadır. Yani bir kısım İngiliz halkının Brexit'e taraf olmasının göç ile ilgili dayandığı bir temel vardır. Ancak bunun kaynak coğrafyasının Avrupa dışı olması ve emek piyasası ile ilgili olması çok muhtemel değildir. Yani Brexit yanlıları da karşıtları da olsa, İngiltere’ye olan göçün kaynak coğrafyasının Avrupa dışı olduğu ve emek piyasasındaki olumsuzluklar üzerine kurulu argüman, göç istatistikleri ve elde edilen ampirik bulgularla desteklenmemektedir. Buradaki sorunun temelinde toplumsal endişelerin var olduğu, bunun altında ise güvenlik, suç, eğitim veya sağlık gibi yerel hizmet taleplerinin getirdiği olumsuz etkilerinin yanında Avrupalılık kimliğinin zaman içinde kaybolacağı yönündeki endişelerin yansıması ile oluşan milliyetçi söylemlerin bulunduğunu söyleyebiliriz.

Diğer taraftan 2011 yılında Suriye'de başgösteren iç karşıklıklar dolayısıyla oluşan göç akını, Türkiye’yi önemli ölçüde etkilemiş, Türkiye son dönemde dünyada en fazla mülteci kabul eden ülke konumuna gelmiştir. İngiltere'nin Brexit referandumunda, Türkiye ile AB arasında akdedilen Geri Kabul Anlaşması bahane edilerek, Türkiye'nin Birliğe olası üyeliğinin hem Türk vatandaşlarının hem de Suriye'den göç edenlerin İngiltere'ye akın edecekleri iddiaları gündeme taşınmış ve bu yöndeki propagandalar da kabul görmüş olacak ki Brexit referandumunda $\mathrm{AB}$ ve göç karşıtları başarılı olmuştur. Ancak Türkiye-AB Geri Kabul Anlaşması'na İngiltere ile birlikte İrlanda ve Danimarka dâhil edilmemiş, bu üye ülkeler dişındaki diğer tüm AB üyesi ülkeler Anlaşma kapsamına alınmıştır. Diğer taraftan çalışmada kullanılan son 30 yıllık dönem içerisinde gerçekleşen göç istatistiklerine bakıldığında Türkiye üzerinden Suriye kaynaklı göçün İngiltere için sorun yaratacak düzeyde gerçekleşmediği görülmektedir. Bu durum Brexit yanlılarınca kulanılan göç ile ilgili endişelerin, Türkiye ve/veya Suriye kaynaklı olmadığını, bu durumun Avrupa ülkelerinden özellikle AB ve AB içerisinde eski Doğu Avrupa'nın Birliğe son katılan ülkelerinden kaynaklandığını göstermektedir. İngiltere'nin AB'den ayrılışının en önemli gerekçelerinden birisi göçtür. Ancak bu göçün kaynağı Avrupa dışı değil, özellikle AB üyesi ülkelerdir.

Dolayısıyla bu çalışmanın türettiği sonuçlar arasında, İngiltere'nin AB'den ayrılış sürecinin başlangıçtan sonuna kadar göç sorunu ile ilişkilendirildiği gerçeğini belirtmek gerekir. Ayrıca İngiltere'de Brexit sürecinde göç ile ilgili ortaya çıkan sorun kaynak coğrafya ile ilgili veya ekonomik etkilere yönelik olmaktan daha ziyade toplumun göçle birlikte değişmek durumunda kalan sosyolojik yapısı ve bunun getirdiği başta güvenlik odaklı endişelerdir. Bununla birlikte göç nedeniyle Avrupalılık kimliğinin zaman içinde yitirileceği yönündeki endişeler dolayısıyla siyasette artan milliyetçilik söylemleri de Avrupa'nın liberal ve çok kültürlülüğe dayalı yapısını tehdit eder durumdadır. Diğer taraftan İngiltere'nin Brexit süreci ile gündeme gelen Suriye ve Türkiye kaynaklı göç endişesi ise siyasi bir propaganda olmaktan öte gerçekçi değildir. 


\section{KAYNAKLAR}

AA (Anadolu Ajansı) (2020, Ocak 29). Brexit'e son nokta konuluyor. [Erişim: 01.02.2020, https://www.aa.com.tr/tr/dunya/brexite-son-nokta-konuluyor/1717663]

Aljazeera Turk (2013, Ocak 23). Cameron'dan AB referandumu sözü. [Erişim: 13.06.2019, http://www.aljazeera.com.tr/haber/camerondan-ab-referandumu-sozu]

ABB (Avrupa Birliği Bakanlığı) (2019). Türkiye-AB Vize Muafiyeti Süreci ve Geri Kabul Anlaşması Hakkında Temel Sorular ve Yanitlarl. [Erişim: $\quad 10.02 .2019$, https://www.ab.gov.tr/files/pub/turkiye_ab_vize_muafiyeti_sureci_ve_geri_kabul_anlasmasi_hakkinda_temel_sorular_ve_yanitlari.pdf]

ABGS (Avrupa Birliği Genel Sekreterliği) (2011). Avrupa Birliği Anlaşması ve Avrupa Birliği’nin İşleyişi Hakkında Anlaşma. [Erişim: 20.09.2019, https://www.ab.gov.tr/files/pub/antlasmalar.pdf]

Balkır, C. (2010). Uluslararası Ekonomik Bütünleşme: Kuram Politika ve Uygulama AB ve Dünya Örnekleri, İstanbul: İstanbul Bilgi Üniversitesi Yayınları.

BBC (2013, Ocak 23). David Cameron promises in/out referendum on EU. [Erişim: 15.03.2021, https://www.bbc.com/news/uk-politics-21148282]

BBC (2015, Mayıs 08). Ingiltere'de bir seçim üç lidere mal oldu. [Erişim: 20.09.2019, https://www.bbc.com/turkce/haberler/2015/05/150508_ingiltere_secim_analiz]

BBC (2016-a, Temmuz 04). The Nigel Farage story. [Erişim: 03.03.2021, https://www.bbc.com/news/ukpolitics-36701855]

BBC (2016-b, Haziran 20). Cameron: Türkiye AB üyesi olacak diye hayır oyu kullanmayın. [Erişim: 10.10.2019, https://www.bbc.com/turkce/haberler/2016/06/160619_cameron_turkiye]

BBC (2019, Mayıs 27). Avrupa Parlamentosu seçimi: Ingiltere'de Brexit partisi zafer kazandl, iktidardaki Muhafazakâr Parti yüzde 9'a geriledi. [Erişim: 30.10.2019, https://www.bbc.com/turkce/haberler-dunya48417901]

Boswell, C. (2007). Migration Control in Europe after 9/11: Explaining the Absence of Securitisation. Journal of Common Market Studies. 45 (3), 589-610.

Boyle, C. (2018). Just what is the UK's problem with Europe? [Erişim: 10.09.2019, https://www.cnbc.com/2015/05/27/why-would-the-uk-want-to-leave-the-eu.html]

Canpolat, H., \& Arıner H. O. (2012). Küresel Göç ve Avrupa Birliği ile Türkiye ’nin Göç Politikalarının Gelişimi. Ankara: ORSAM Yayınları.

CEU (Council of The European Union) (2009). European Security Strategyen a Secure Europe in a Better World. Belgium: European Communities.

Clarke, H. D., Goodwin, M., \& Whiteley, P. (2017). Brexit: Why Britain Voted to Leave the European Union. April. Cambridge: Cambridge University Press.

CNN (2016, Temmuz 14). Theresa May becomes new British Prime Minister. [Erişim: 20.09.2019, https://edition.cnn.com/2016/07/13/europe/theresa-may-david-cameron-british-prime-minister/]

Cookman, L. (2016). What if Turks talked about Britons the way Vote Leave talks about Turkey? [Erişim: 25 May 2016, https://www.theguardian.com/commentisfree/2016/may/25/vote-leave-turkey-british-migrants-turks-ankara-eu]

Coulter, S. (2016). The UK Labour Market and the Great Recession. İçinde, M. Myant, S. Theodoropoulou, A. Piasna (Edt.), Unemployment, Internal Devaluation and Labour Market Deregulation in Europe (197-227) Belgium: European Trade Union Institute [Erişim: 01.03.2021, http://eprints.lse.ac.uk/65615/1/Coulter_The\%20UK\%20labour\%20market\%20and\%20the\%20great\%20recession.pdf]

Çakı, F. (2014). Arap Baharı: İslam Üzerine Söylemsel Dönüşümün Habercisi Mi?. Akademik Incelemeler Dergisi. 6 (2), 123-138. 
Dailymail (2016, Haziran 29). Merkel's open door policy has brought 'chaos' to Europe, claims George Soros as German leader is blamed for Brexit over her failure to deal with migrant crisis. [Erişim: 20.10.2019, https://www.dailymail.co.uk/news/article-3666511/Merkel-s-open-door-policy-caused-Britain-leave-EU-German-leader-blamed-Brexitfailure-deal-migrant-crisis-open-arms-immigration-policy-html]

Descy, P. (2014). Projected labour market imbalances in Europe: Policy challenges in meeting the Europe 2020 employment targets, OECD/European Union, Matching Economic Migration with Labour Market Needs (315-333) içinde. OECD Publishing. (Http://dx.doi.org/10.1787/9789264216501-12-en). (Bu rapor, Avrupa Komisyonu ve OECD tarafindan ortaklaşa düzenlenen "OECD-EU Dialogue on Mobility And International Migration: Matching Economic Migration With Labour Market Needs" (Brüksel, 24-25 Şubat 2014) adlı konferansında sunulan çalışmalardan oluşmaktadır.)

Dustmann, C., Fabbri, F., \& Preston, I. (2005). The Impact of Immigration on the UK Labour Market. Economic Journal. 115, F324-F341.

EC (European Commission) (2015, May1s 12). Communication From The Commission To The European Parliament, The Council, The European Economic And Social Committee And The Committee Of The Regions A European Agenda On Migration. Brussels. [Erişim: 26.02.2021, https://eur-lex.europa.eu/legalcontent/EN/TXT/qqid=1485255362454\&uri=CELEX:52015DC0240]

EC (European Commission) (2016-a, May1s 04)). Turkey's Progress On The Visa Liberalisation Roadmap. [Erişim: 15.02.2019, https://ec.europa.eu/home-affairs/sites/homeaffairs/files/what-we-do/policies/european-agendamigration/background-information/docs/20160504/turkey_progress_visa_liberalisation_roadmap_en.pdf]

EC (European Commission) (2016-b). Managing The Refugee Crisis Eu-Turkey Statement: Progress Report. [Erişim: 07.02.2019, https://ec.europa.eu/home-affairs/sites/homeaffairs/files/what-we-do/policies/european-agendamigration/background-information/docs/20160615/factsheet_implementation_of_the_eu-turkey_statement_en.pdf]

EC (European Commission) (2016-c). Second Report on the progress made in the implementation of the EU-Turkey Statement. [Erişim: 07.02.2019, https://ec.europa.eu/home-affairs/sites/homeaffairs/files/what-we-do/policies/europeanagenda-migration/proposal-implementation-package/docs/20160615/2nd_commission_report_on_progress_made_in_the_implementation_of_the_euturkey_agreement_en.pdf]

EC (European Commission) (2016-d, Ekim 04)). Managing the Refugee Crisis, EU-Turkey Statement. [Erişim: 15.02.2019, http://europa.eu/rapid/press-release_MEMO-16-3218_en.htm]

EC (European Commission) (2017). The EU and the Migration Crisis. [Erişim: 10.12.2020, https://op.europa.eu/en/publication-detail/-/publication/e9465e4f-b2e4-11e7-837e-01aa75ed71a1]

EC (European Commission) (2021). European Agenda on Migration - Legislative document. [Erişim: 03.03.2021, https://ec.europa.eu/home-affairs/what-we-do/policies/european-agenda-migration/proposal-implementation-package_en]

EP (European Parliament) (2019, Ekim 15-16). Tampere European Council Presidency Conclusions. [Erişim: 10.04.2019, http://www.europarl.europa.eu/summits/tam_en.htm]

EU (European Union) (2018). Eurostat Regional Yearbook 2018. Luxembourg: Publications Office of the European Union.

EUCO (European Council) (2016, Şubat 18-19). European Council meeting (18 and 19 February 2016) - Conclusions. [Erişim: 15.03.2021, https://www.consilium.europa.eu/media/21787/0216-euco-conclusions.pdf]

Euronews (2019, Mayıs 24). Brexit'e karşılyd, Brexit için geldi, Brexit sonu oldu: Ingiltere Başbakanı May görevi biraklyor. [Erişim: 20.10.2019, https://tr.euronews.com/2019/05/24/brexit-icin-geldi-brexit-sonu-oldu-ingilterebasbakani-theresa-may-gorevi-birakiyor]

Euronews (2020-a, Ocak 02). Avrupa'yı son 10 senede değiştiren en büyük 10 olay. [Erişim: 03.02.2020, https://tr.euronews.com/2020/01/02/avrupa-y-son-10-senede-degistiren-en-buyuk-10-olay]

Euronews (2020-b, Şubat 01). Ingiltere'nin AB serüveni resmen sona erdi: Brexit sürecinde son 4 yllda neler yaşandı? [Erişim: 05.02.2020, https://tr.euronews.com/2020/01/31/ingiltere-avrupa-birligi-seruveni-resmen-bitiyor-brexitkronolojisi-4-yilda-neler-yasandi]

Geddes, A. (2001). International Migration and State Sovereignty in an Integrating Europe. International Migration. 39 (6), 21-42. 
BŞEÜ Sosyal Bilimler Dergisi

6 (2), 484-503, 2021
BSEU Journal of Social Sciences

https://doi.org/10.33905/bseusbed.1027257

Güleç, C. (2015). Avrupa Birliği’nin Göç Politikaları ve Türkiye’ye Yansımaları. TESAM Akademi Dergisi. 2 (2), 81-100.

Haas Hein de, C. S., \& Miller, M. J. (2020). The Age of Migration: International Population Movements in the Modern World. Sixth Edition. New York: Guildford Press.

Hammar, T. (2006). Democracy and the Nation-State: Aliens, Denizens and Citizens in a World of International Migration. Avebury: Aldershot. 74 (S1), 25-38.

Hansen, R. (2003). Migration to Europe Since 1945: Its History and Its Lessons. The Political Quarterly.

Huysmans, J. (1995). Migrants as a security problem: dangers of 'securitizing' societal issues. R. Miles and D. Thränhardt. (Edt.) Migration and European Integration. The Dynamics of Inclusion and Exclusion (53-72) içinde. London: Pinter.

Huysmans, J. (2000).The European Union and the Securitization of Migration. Journal of Common Market Studies. 38 (5), 751-777.

Huysmans, J. (2002). Defining social constructivism in security studies: the normative dilemma of writing security. Alternatives. 27, 41-62.

Huysmans, J. (2006). The Politics of Insecurity- Fear, Migration and Asylum in the EU. London: Routledge.

Independent (2021, Ocak 16). Brexit group's website suspended in row over its bid to move to EU. [Erişim: 10.03.2021, https://www.independent.co.uk/news/uk/politics/leave-eu-brexit-website-arron-banks-b1788267.html]

IOM (International Organization for Migration) (2017). World Migration Report 2018. Switzerland: International Organization for Migration,

Ipsos MORI (2016). Ipsos MORI June 2016 Political Monitor Topline Results. [Erişim: 02.03.2021, https://www.ipsos.com/sites/default/files/migrations/en-uk/files/Assets/Docs/Polls/eu-referendum-topline-23-june-2016.pdf, (1-4)]

Karyotis, G. (2007). European Migration Policy in the Aftermath of September 11. Innovation: The European Journal of Social Science Research. 20 (1), 1-17.

King, E., \& Aaron, F., (2018, Ocak). Brexit and the future of immigration in the UK and EU. Financier Worldwide. [Erişim: 20.09.2019, https://www.financierworldwide.com/brexit-and-the-future-of-immigration-in-the-uk-andeu\#.XkXIZGgzaM]

Maas, W. M. (2008, Ocak). Fleeing to Europe: Europeanization and the Right to Seek Refugee Status. International Institute of Social Studies of Erasmus University (ISS). Workin Paper No:454. Netherlands. [Erişim: 11.03.2021, https://repub.eur.nl/pub/18740/wp454.pdf, (1-50)]

Mason, R. (2015, Kasım 16). Nigel Farage Accuses Muslims in UK Of 'Split Loyalties'. [Erişim: 02.03.2021, https://www.theguardian.com/politics/2015/nov/16/nigel-farage-accuse-british-muslims-conflicting-loyalties]

ONS (Office for National Statistics) (2013, Ocak 30). 2011 Census: Quick Statistics for England and Wales, March 2011. Office for National Statistics, Statiscal Bulletin. [Erişim: 30.01.2020, https://www.ons.gov.uk/peoplepopulationandcommunity/populationandmigration/populationestimates/bulletins/2011 censusquickstatisticsfor englandandwales/2013-01-30]

ONS (Office for National Statistics) (2015, Eylül 27). Population by Country of Birth and Nationality Report: August. Office for National Statistics, Statiscal Bulletin. [Erişim: 10.12.2019, https://www.ons.gov.uk/peoplepopulationandcommunity/populationandmigration/internationalmigration/articles/populationbycountryofbirth andnationalityreport/2015-09-27]

ONS (Office for National Statistics) (2019, Ekim 28). Population of the UK by country of birth and nationality: July 2018 to June 2019. Office for National Statistics, Statiscal Bulletin. [Erişim: 16.12.2019, https://www.ons.gov.uk/peoplepopulationandcommunity/populationandmigration/internationalmigration/bulletins/ukpopulationbycountryofb irthandnationality/july2018tojune2019] 
BŞEÜ Sosyal Bilimler Dergisi

6 (2), 484-503, 2021
BSEU Journal of Social Sciences

https://doi.org/10.33905/bseusbed.1027257

Özerim, G. (2017). Göç Konusunun Birleşik Krallık'ta AB Referandumu Sürecindeki Yeri. İçinde, E. Esen ve D. Şekeroğlu. (Edt.). BREXIT- Elveda Avrupa İngiltere'nin AB'den Ayrılmasından Sonra Avrupa Bütünleşmesi ve Türkiye-AB İlişkilerinde Firsatlar ve Tehditler (83-95). Ankara: Siyasal Kitapevi.

Özkural Köroğlu, N., \& Yüksel Çendek, S. (2015). Toplumsal Güvenlik, Kimlik, Bütünleşme Bağlamında Avrupa Şüpheciliği: Cameron Dönemindeki Avrupa Şüpheciliğinin İçerik Analizi. Akademik Incelemeler Dergisi. 10 (2), 191-216, DOI: 10.17550/aid.57800.

Pirro, A., \& Kessel, S. (2017). United in Opposition? The Populist Radical Right's EU-Pessimism in Times of Crisis. Journal of European Integration. 39 (4), 405-420.

Portes, J. (2016). Immigration, free movement and the EU referendum. National Institute Economic Review, 236, 14-22. doi:10.1177/002795011623600103

Powell, K. (2017). Brexit Positions: Neoliberalism, Austerity and Immigration-the (Im) possibilities? of political revolution. Dialectical Anthropology. 41 (3), 225-240.

Schmelz, A. (2008). (Post) Colonial Migration and Remembrance (Policy) in European Immigration Societies: Perspectives of a Cosmopolitan European Citizenship Education. [Erişim: 02.04.2019, http://citeseerx.ist.psu.edu/viewdoc/download?doi=10.1.1.600.8039\&rep=rep1\&type=pdf]

Serricchio, F., Tsakatika, M., \& Quaglian, L. (2013). Euroskepticism and Global Financial Crisis. Journal of Common Market Studies. 51 (1), 51-64.

Springford, J., Tilford, S., McCann, P., Whyte, P., \& Odendahl, C. (2016). The Economic Consequences of Leaving the EU: The Final Report Of The Cer Commission On Brexit 2016. Centre for European Reform - CER. London. [Erişim: 15.01.23020, https://www.cer.org.uk/sites/default/files/smc2016_26april2016.pdf] 151-179.

Stalker, P. (2002). Migration Trends and Migration Policy in Europe. International Migration. 40 (5),

Startin, N. (2015). Have We Reached A Tipping Point? The Mainstreaming of Euroscepticism in the UK. International Political Science Review. 36 (3). DOI: 10.1177/0192512115574126, 311-323.

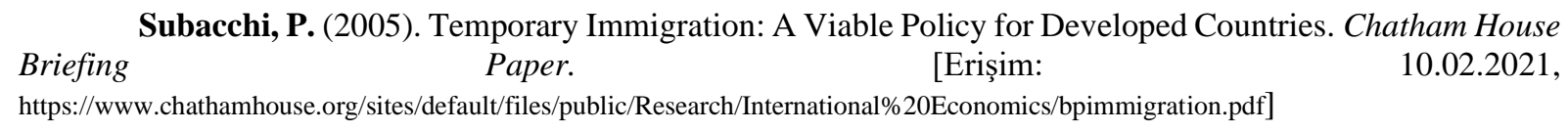

T.C. Dışişleri Bakanlığı (2019). Birleşik Krallık'ı Siyasi Görünümü. [Erişim: 19.11.2019, http://www.mfa.gov.tr/ingiltere-siyasi-gorunumu.tr.mfa]

T.C. Dışişleri Bakanlığı (2020). Türkiye AB Arasında 18 Mart'ta Varılan Mutabakata İlişkin Soru Cevaplar. [Erişim: 02.01.2020, http://www.mfa.gov.tr/turkiye-ab-ara-sinda-18-mart_ta-varilan-mutabakata-iliskin-sorucevaplar.tr.mfa]

The Guardian (2010, Ocak 11). Tories would limit immigration to 'tens of thousands' a year, says Cameron. [Erişim: 20.02.2021, https://www.theguardian.com/uk/2010/jan/11/david-cameron-limit-immigration]

The Telegraph (2019, Temmuz 24)). Boris Johnson promotes Brexit loyalists in biggest Cabinet cull in 60 years. [Erişim: 30.10.2019, https://www.telegraph.co.uk/politics/2019/07/24/boris-johnson-prime-minister-new-cabinet-latest-news-speech]

Tokgöz, G. (2006). Uluslararası Emek Göçü, İstanbul: İstanbul Bilgi Üniversitesi Yay.

UNDESA (United Nations Deparment of Economic and Social Affairs) (1998). Recommendations on Statistics of International Migration, Revision 1, Statics Division. United Nations Deparment of Economic and Social Affairs. New York. [Erişim: 03.03.2019, https://unstats.un.org/unsd/publication/seriesm/seriesm_58revle.pdf]

UNDESA (United Nations Deparment of Economic and Social Affairs) (2019). Migrant Stock By Origin and Destination-2019. United Nations Deparment of Economic and Social Affairs. New York. [Erişim: 02.02.2020, https://www.un.org/en/development/desa/population/migration/data/estimates2/data/UN_MigrantStockByOriginAndDestination_2019.xlsx]

UNHCR (United Nations High Commissioner for Refugees) (2020). Figures at a Glance, Statistical Yearbooks. [Erişim: 16.12.2020, https://www.unhcr.org/figures-at-a-glance.html] 


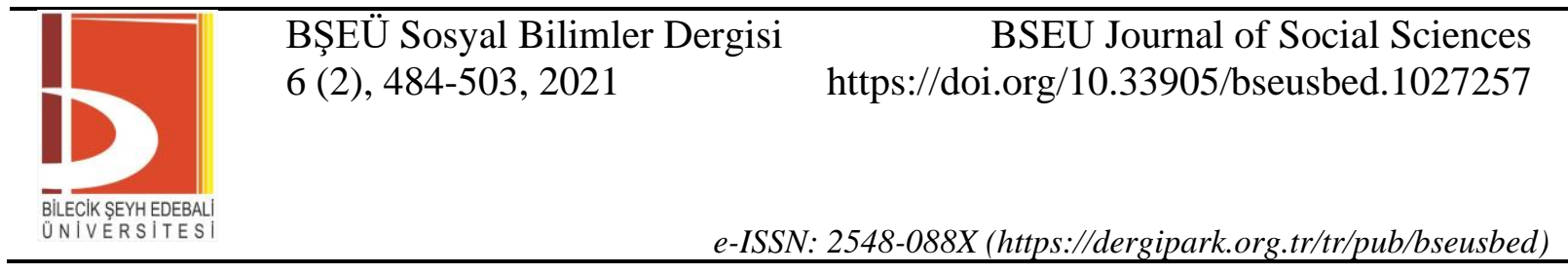

UKIP (2015). Believe in Britain UKIP Manifesto 2015. [Erişim: 03.03.2021, https://d3n8a8pro7vhmx.cloudfront.net/ukipdev/pages/1103/attachments/original/1429295050/UKIPManifesto2015.pdf?1429295050]

Utku, D. E., \& Köroğlu, N. Ö. (2020). Anti-Immigration vs Anti-EU: Political Discourse Analysis of Brexit Decision of The UK. Hitit Üniversitesi Illahiyat Fakültesi Dergisi, Haziran, 19 (1), 1-34.

Wadsworth, J. (2015). Immigration and the UK Labour Market. Centre for Economic Performance (CEP). London: London School of Economics and Political Science.

Wadsworth, J., Dhingra, S., Ottaviano, G., \& Reenen, J., (2016). Brexit and the Impact of Immigration on the UK, Centre for Economic Performance (CEP), London: London School of Economics and Political Science.

Waever, O., Buzan, B., Kelstrup, M., \& Lemaitre, P. (1993). Identity, Migration and the New Security Agenda in Europe. New York: St.

Why Vote Leave (2021). Why Vote Leave, [Erişim: 10.02.2021, http://www.voteleavetakecontrol.org/why_vote_leave.html]

Zimmermann, K. F. (2005). Introduction: What We Know About European Migration? European Migration: What Do We Know?, Klaus F. Zimmermann (Edt.). Oxford: Oxford University Press. 